\title{
MIRANDA DECONSTITUTIONALIZED: WHEN THE \\ SELF-INCRIMINATION CLAUSE AND THE GIVIL RIGHTS ACT COLLIDE
}

\author{
SUSAN R. KLEIN†
}

\section{INTRODUCTION}

The unthinkable happens-you are arrested. You are taken to the police station, put in an interrogation room, and read your rights. We all know them from television by now:

You have the right to remain silent. If you choose to give up this right, anything you say can and will be used against you in a court of law. You have the right to consult with an attorney, and to have the attorney present during interrogation. If you cannot afford an attorney, one will be appointed to represent you. Do you understand these rights? ${ }^{1}$

Of course you do; you are a law professor, an attorney, a wellinformed citizen.

"I demand to see my lawyer and refuse to answer any questions."

"Too bad, buddy, we're short on patience today. You're gonna talk to us without your lawyer."

"What? I demand to see my lawyer!"

"You have to comply."

"I'll sue."

(general laughter by officers present)

After hours of nonstop interrogation, one of five possible outcomes emerges: you are guilty and "spill your guts"; you are innocent but confess or make damaging admissions; you are guilty but have the exceptional fortitude to remain quiet; you are innocent and manage to remain silent; you are innocent and eventually convince the police to release you or at least end the interrogation. Except for the first two situations, in which you may have the limited remedy of having your statement excluded from the prosecutor's case-inchief, ${ }^{2}$ there are no remedies available to you for the violation of

† A.B. 1983, Wellesley College; J.D. 1989, Boalt Hall School of Law, University of California at Berkeley. Assistant Professor of Law, University of Texas at Austin.

1 The Supreme Court established the general substantive requirements for police officers in Miranda v. Arizona, 384 U.S. 436 (1966).

2 The introduction of a statement taken in violation of Miranda and/or the SelfIncrimination Clause will be allowed if it is later determined to have been harmless 
your so-called "rights."

This Article will examine the Supreme Court's backpedaling on the warnings required by Miranda $v$. Arizona ${ }^{3}$ and how that decision's attendant exclusionary rule has affected both the manner in which investigations are conducted by police departments in this country and the remedies available to citizens who are subject to unlawful government conduct. I propose that current developments in Fifth Amendment jurisprudence actually encourage law enforcement officials to violate the standards of conduct imposed upon them by the Miranda decision, and that current developments in civil rights jurisprudence make impossible a successful action based upon a violation of either Miranda or the privilege against compelled self-incrimination. Thus, a rational police officer in today's world will (and often does) ignore the dictates of Miranda. This problem can be solved only if the Supreme Court reconstitutionalizes Miranda, at least to the extent necessary to enforce those restraints on state and federal officials that it initially found crucial to properly safeguarding an individual's Fifth Amendment privilege against self-incrimination. Failing this, the Court should cease promulgating prophylactic rules that it cannot or will not enforce, both to avoid losing institutional prestige and to curb the shift in constitutional interpretative authority from itself to the executive branches of state and federal governments. ${ }^{4}$

In Part I, I detail the primary obstacles to enforcing Fifth Amendment values. First, I briefly describe the already welldocumented evolution of the prohibition against compelled selfincrimination, ${ }^{5}$ which after reaching the pinnacle of protection in Escobedo v. Illinois, ${ }^{6}$ settled into its most balanced and modern

error. See Arizona v. Fulminante, 499 U.S. 279, 306-12 (1991) ("[T]he Court has applied harmless error analysis to a wide range of errors and has recognized that most constitutional errors can be harmless."); infra notes 56-57 and accompanying text.

384 U.S. 436 (1966).

4 This argument holds true regardless of one's agreement with the normative views underlying Miranda. Whether one believes that Miranda was a bad decision that will lead to the release of additional criminals to prowl our already unsafe streets or that the Miranda warnings were a necessary obstacle in the path of an overly powerful State's ability to trample an individual's dignity, it should be possible to reach agreement concerning whether, on any particular topic, the Court ought to issue commands that are not going to be followed.

${ }^{5}$ See U.S. CONST. amend. V (stating that "nor shall any person . . . be compelled in any criminal case to be a witness against himself").

${ }^{6} 378$ U.S. 478 (1964). 
approach in Miranda $v$. Arizona. The Miranda decision offered the indispensable advantages of providing a "bright-line" rule for police officers to follow, aiding courts in adjudication by presuming confessions to be valid when the prescribed warnings are given, and fairly evaluating the often competing interests of performing traditional law enforcement functions and protecting individual Fifth Amendment rights of those suspected of committing a crime. I then trace the privilege's subsequent decline in what I term the Miranda decision's deconstitutionalization, a process that began almost from its inception and reached its nadir when the Department of Justice recommended that Miranda be overruled as an illegitimate act of judicial policymaking. ${ }^{7}$ There are now so many exceptions to Miranda's exclusionary rule that it makes more sense on a practical level to violate it than to obey it. Additionally, if the Miranda decision truly has no constitutional mooring, the Court lacks authority pursuant to Article III of the United States Constitution to impose its mandates upon state actors.

Second, I outline the detrimental and perhaps unintended effect of this deconstitutionalization on actions brought against state and local officials, pursuant to the Civil Rights Act of 1871 (§ 1983)

' See Office of Legal Policy, U.S. Dep't Of Justice, Truth in Criminal Justice, REPORT NO. 1, REPORT TO THE ATTORNEY GENERAL ON THE LAW OF PRETRIAL INTERROGATION (1986), reprinted in 22 U. MICH. J.L. REF. 437, 542-49 (1989) [hereinafter DEPARTMENT OF JUSTICE REPORT] (asserting that Miranda "constituted a usurpation of legislative and administrative powers, thinly disguised as an exercise in constitutional exegesis, which rested on fictions and specious arguments"). This report was written during the tenure of former Attorney General Edwin Meese and adopted by the subsequent Republican attorneys general. Although there has been no official declaration on this issue, I doubt that the report reflects the present position of the Department under Attorney General Janet Reno.

${ }^{8}$ Section 1983 states,

Every person who, under color of any statute, ordinance, regulation, custom, or usage, of any State or Territory or the District of Columbia, subjects, or causes to be subjected, any citizen of the United States or other person within the jurisdiction thereof to the deprivation of any rights, privileges, or immunities secured by the Constitution and laws, shall be liable to the party injured in an action at law, suit in equity, or other proper proceeding for redress. For the purposes of this section, any Act of Congress applicable exclusively to the District of Columbia shall be considered to be a statute of the District of Columbia.

42 U.S.C. § 1983 (1988).

Similar actions may be brought against federal officials. See Bivens v. Six Unknown Named Agents of Fed. Bureau of Narcotics, 403 U.S. 388, 397 (1971) (holding that plaintiff could sue federal narcotics agents for injuries suffered through the agents' alleged violation of the Fourth Amendment). The analysis contained both in the $\S 1983$ case law and in this Article applies with equal force to these so-called 
and based upon allegations of police-coerced confessions. I will briefly synopsize and analyze most of the case law in this area from 1968 to the present. Those courts that allow a civil rights action based on an unwarned statement do so on the basis of Fourteenth Amendment substantive due process notions ${ }^{9}$ or on an expansive reading of the Fifth Amendment itself. Those courts that dismiss a civil rights action based on unwarned confessions do so based upon one or more of the following considerations: (1) Miranda warnings are merely prophylactic rules, rather than constitutional prerequisites; (2) the Fifth Amendment cannot be violated unless a statement is used in a criminal proceeding; (3) the doctrine of collateral estoppel prevents relitigation of the voluntariness of a confession; (4) when a peace officer testifies at a criminal trial, he is not acting under "color of law"; (5) law enforcement officials are not the proximate cause of the admission of coerced confessions; and (6) absolute or qualified immunity protects the government actors involved. I suggest that those courts that dismiss these civil rights claims are more faithfully following Supreme Court mandates. I further argue that the confluence of present legal doctrines bars virtually all $\S 1983$ actions based on alleged violations not only of Miranda but of the Fifth Amendment itself.

In Part II, I outline the advantages of allowing some remedy for Miranda violations and discuss the consequences of failing to do so. Most important, the elimination of Miranda would seriously infringe upon personal liberties by shifting the responsibility for interpreting the Constitution from the judiciary to law enforcement officials. Additionally, permitting some remedy would vindicate federal rights and foster Miranda's symbolic value as an ideal to be integrated into the behavioral norms of law enforcement entities and as an expression of society's commitment to treat each member, even one charged with a heinous crime, with respect.

Finally, in Part III, I consider various avenues available to support the Self-Incrimination Clause. Initially, I explore the possibility of basing a civil rights action upon either the deservedly maligned doctrine of substantive due process or a broader interpretation of the Fourth Amendment. I further suggest the more comprehensive solution of reconstitutionalizing Miranda and its exclusionary rule, either by true constitutional interpretation of the

\section{Bivens actions.}

${ }^{9}$ See U.S. CONST. amend. XIV, $§ 1$ (stating “nor shall any State deprive any person of life, liberty, or property, without due process of law"). 
underlying guarantees of the Fifth Amendment or by recognizing and refining a concept of "constitutional common law"10 that may be only conditionally or temporarily required. Each of these solutions would permit some or all of the following remedies for a Miranda violation: the exclusionary rule applied solely to the prosecutor's case-in-chief, the exclusion of all collateral uses of such evidence, and money damages or injunctive relief. I conclude that although the legal and policy arguments against traversing these avenues are sound, they cannot ultimately prevail, lest the Court be unable to discharge its role as the ultimate interpreter of the Constitution ${ }^{11}$ in the Fifth Amendment and other vital areas.

\section{OBSTACLES TO ENFORCEMENT}

There are two primary obstacles to enforcement of the SelfIncrimination Clause. The first is the Court's deconstitutionalization of the Miranda warnings. Initially, this change permitted gradual inroads into Miranda's exclusionary rule. Each inroad allowed greater use of statements taken in violation of Miranda and hence made it more attractive to violate the rule. Eventually, prosecutors and legal scholars began to argue that Miranda was itself an illegitimate decision and that the Court had no authority under Article III of the Constitution to promulgate Miranda's exclusionary rule or, in fact, any prophylactic rules. Such reasoning has emboldened certain Court members and Justice Department officials to advocate overruling Miranda entirely or utilizing a largely ignored federal statute ${ }^{12}$ to evade its requirements. The second obstacle to protecting the privilege against self-incrimination

${ }^{10}$ This phrase was coined by Henry P. Monaghan. See Henry P. Monaghan, The Supreme Court 1974 Term-Foreword: Constitutional Common Law, 89 HARV. L. REV. 1 (1975). According to Monaghan,

a surprising amount of what passes as authoritative constitutional "interpretation ${ }^{n}$ is best understood as something of a quite different order-a substructure of substantive, procedural, and remedial rules drawing their inspiration and authority from ... various constitutional provisions; in short, a constitutional common law subject to amendment, modification, or even reversal by Congress.

Id. at 2-3. Much of the analysis contained in part III.C of this Article has its genesis in Professor Monaghan's groundbreaking work.

"See Marbury v. Madison, 5 U.S. (1 Cranch) 137, 146-47 (1803) (holding that Article III of the Constitution gives the Court the power to make authoritative determinations of constitutional law, and thus the Court has the power to declare acts of Congress unconstitutional).

${ }^{12}$ See 18 U.S.C. $\$ 3501$ (1988). 
concerns the development of Fifth Amendment and civil rights jurisprudence in such a manner as to exclude any possible damage action for violation of either the Miranda dictates or the SelfIncrimination Clause itself.

\section{A. Miranda's Deconstitutionalization}

Up until the early 1960s, the admissibility of a defendant's statements in a criminal trial in state court depended upon an assessment of the "totality of the circumstances" to determine whether the confession was the product of an essentially free and unconstrained choice by its maker. ${ }^{13}$ If it was not, the introduction of such a statement violated the Due Process Clause of the Fourteenth Amendment. ${ }^{14}$ The Court looked to such factors as the conduct of the police in intimidating the suspect and the characteristics of the suspect that might make him susceptible to coercion, such as his age, intelligence, education, psychological problems, and physical limitations. ${ }^{15}$

This standard was modified by three events occurring in the mid-1960s. First, the Fifth Amendment's privilege against selfincrimination was incorporated into the Fourteenth Amendment and thus made applicable to the states. ${ }^{16}$ Second, the Sixth Amendment's right to assistance of counsel was extended preindictment to mere police interrogation of a "prime suspect,"

${ }^{13}$ See infra note 15 and accompanying text.

${ }^{14}$ The admissibility of confessions in federal court was and is regulated by the Fifth Amendment. See Bram v. United States, 168 U.S. 532, 542 (1897) (holding that "whether a confession is incompetent because not voluntary . . . is controlled by that portion of the Fifth Amendment . . . commanding that no person 'shall be compelled in any criminal case to be a witness against himself").

${ }^{15}$ See, e.g., Haynes v. Washington, 373 U.S. 503, 507 (1963) (concerning a suspect who was not allowed to call his wife until after he confessed); Spano v. New York, 360 U.S. 315, 323 (1959) (concerning a suspect who was induced to confess through, inter alia, sympathy falsely aroused); Payne v. Arkansas, 356 U.S. 560, 564-66 (1958) (concerning a suspect who was promised protection against an angry mob outside the jailhouse door if he confessed); Brown v. Mississippi, 297 U.S. 278, 281-83 (1936) (concerning suspects who were tortured by officers until they confessed). As exemplified by the above cases, the constitutional test matured during this time period from inquiring whether there was compulsion by torture to whether it was the accused's free choice to admit, deny, or refuse to answer. See Spano, 360 U.S. at 321 (" $[\mathrm{A}] \mathrm{s}$ law enforcement officers become more responsible, and the methods used to extract confessions more sophisticated, our duty to enforce federal constitutional protections does not cease. It only becomes more difficult because of the more delicate judgments to be made.").

${ }^{16}$ See Malloy v. Hogan, 378 U.S. 1, 3 (1964). 
although for only a brief time. ${ }^{17}$ Finally, the principles embodied in the Fifth Amendment's prohibition against compulsory selfincrimination were implicated by statements taken from suspects during custodial interrogations. ${ }^{18}$ It was the third event that precipitated the requirement that police officers recite the warnings quoted in the first paragraph of this Article.

Although now limited to its peculiar facts, ${ }^{19}$ at the time Escobedo v. Illinois was decided, many commentators feared that its sweeping language regarding the need for counsel before confessions are taken ${ }^{20}$ and its attack on the use of confessions in gener$\mathrm{al}^{21}$ presaged the development of a new rule that would bar both uncounseled confessions and volunteered statements, thus effectively eliminating interrogations. ${ }^{22}$ Instead, two years later in Miranda, the Court specifically permitted volunteered statements, general onthe-scene questioning before a suspect is taken into custody, and incustody interrogation (after the required warnings) based upon an uncounseled waiver. ${ }^{23}$ Despite the objectionable police interrogation tactics that continued to be employed under the old "voluntari-

${ }^{17}$ See Escobedo v. Illinois, 378 U.S. 478, 490-91 (1964). The holding in Escobedo was subsequently limited. See infra note 19 and accompanying text.

${ }^{18}$ See Miranda v. Arizona, 384 U.S. 436, 467 (1966).

${ }^{19}$ See Kirby v. Illinois, 406 U.S. 682, 689 (1972) (distinguishing Escobedo because "the Court has limited the holding of Escobedo to its own facts"); see also Johnson v. New Jersey, 384 U.S. 719, 733-34 (1966) (noting the "precise holding" of Escobedo and discounting its "broad implications").

20 "The fact that many confessions are obtained during this period points up its critical nature as a 'stage when legal aid and advice' are surely needed." Escobedo, 378 U.S. at 488 (quoting Massiah v. United States, 377 U.S. 201, 204 (1964) (quoting Spano v. New York, 360 U.S. 315, 326 (1959) (Douglas, J., concurring))).

${ }^{21}$ "[A] system of criminal law enforcement which comes to depend on the 'confession' will, in the long run, be less reliable and more subject to abuses than a system which depends on extrinsic evidence independently secured through skillful investigation." Id. at 488-89 (footnotes omitted).

22 See, e.g., YALE KAMISAR, POLICE INTERROGation AND CONFESSIONS: EsSaYS IN LAW AND POLICY $161 \mathrm{n} .26$ (1980) (summarizing predictions of commentators concerning Escobedo's impact); Arnold N. Enker \& Sheldon H. Elsen, Counsel for the Suspect: Massiah v. United States and Escobedo v. Illinois, 49 MINN. L. REv. 47, 60-61 (1964) (suggesting that Escobedo "may be creating a novel right not to confess except knowingly and with the tactical assistance of counsel," rather than the Constitution's "right ... not to be compelled to confess"); Roger J. Traynor, The Devils of Due Process in Criminal Detection, Detention, and Trial, 33 U. CHI. L. REv. 657, 669 (1966) (lamenting that the Escobedo rule "apparently makes available to any suspect a fullblown right to counsel at the incipient accusatory stage when police interrogation shifts ... to a probe focusing upon him" without clearly defining when such a shift occurs).

${ }^{23}$ See Miranda v. Arizona, 384 U.S. 436, 444-45 (1966). 
ness" test, ${ }^{24}$ and the more modern coercive tactics designed to "subjugate the individual to the will of his examiner"25 and put him "in such an emotional state as to impair his capacity for rational judgment, ${ }^{26}$ the Court found that police-issued Miranda warnings were sufficient to "dispel the compulsion inherent in custodial surroundings. ${ }^{27}$

Thus, the Miranda decision is best viewed as a compromise between competing interests. ${ }^{28}$ The Miranda court attempted to protect the values enshrined in the Fifth Amendment: ${ }^{29}$ individual

${ }^{24}$ See, e.g., Lisenba v. California, 314 U.S. 219, 240-41 (1941) (holding that despite lawless practices of police interrogators, suspect's self-possession during questioning refuted charge of involuntariness); Brown v. Mississippi, 297 U.S. 278, 283 (1936) (holding that confessions extorted through physical torture were not "free and voluntary").

${ }^{25}$ Miranda, 384 U.S. at 457.

${ }^{26} \mathrm{Id}$. at 465 . The Miranda Court devoted much of its opinion to outlining the abuses suffered by suspects during "menacing police interrogation procedures." Id. at 457. The Court described these abuses through the finding of the Commission on Civil Rights that "some policemen still resort to physical force to obtain confessions." Id. at 446 (citation omitted). The Court also cited to state cases in which such practices as manhandling a defendant, strapping a completely nude defendant to a chair, forcing a defendant to submit to a lie detector test when he needed to use the toilet, and depriving defendants of food and sleep were permitted. See id. at 446 n.7. Finally, the Court reviewed police manuals that advocated deception and the creation of feelings of fear and hopelessness. See id. at 448-55.

${ }^{27} I d$. at 458.

${ }^{28}$ See, e.g., Moran v. Burbine, 475 U.S. 412,433 n.4 (1986) (noting that "the [Miranda] decision . . . embodies a carefully crafted balance designed to fully protect both the defendant's and society's interests"); Laurence A. Benner, Requiem for Miranda: The Rehnquist Court's Voluntariness Doctrine in Historical Perspective, 67 WASH. U. L.Q. 59, 161 (1989) ("Confronted with the storm of controversy that the [Escobedo] decision created, the Court retreated in Miranda, and struck a compromise."); Yale Kamisar, Remembering the "Old World" of Criminal Procedure: A Reply to Professor Grano, 23 U. MICH. J.L. REF. 537, 579 (1990) (arguing that "the Miranda Court sought to strike a balance between the interests of the police and the rights of suspects"); Stephen A. Saltzburg, Miranda v. Arizona Revisited: Constitutional Law or Judicial Fiat, 26 WASHBURN L.J. 1, 21-23 (1986) (suggesting that despite the writings of numerous critics, Miranda was actually a compromise in favor of law enforcement); Stephen J. Schulhofer, Reconsidering Miranda, 54 U. CHI. L. REV. 435, 454 (1987) (" $[\mathrm{F}]$ ar from handcuffing the police, the warnings work to liberate the police. Miranda's much-maligned rules permit the officer to continue questioning his isolated suspect, the very process that the Court[] ... found to be a violation of the [F]ifth [A]mendment."). But see Gerald M. Caplan, Questioning Miranda, 38 VAND. L. REv. $1417,1469-72$ (1985) (arguing that in response to racism against southern Blacks and views of criminals as underdogs and victims, the Miranda Court resolved the competing interests of law enforcement and individuals by focusing on protection of the suspect).

${ }^{29}$ See Miranda, 384 U.S. at 458-60 (tracing the roots of the privilege against selfincrimination from ancient times). 
autonomy, ${ }^{30}$ a preference for an accusatorial system of criminal prosecution, ${ }^{31}$ the fairer trial that results from the exclusion of unreliable testimony, ${ }^{32}$ and the preservation of proper police practices, ${ }^{33}$ while still permitting most interrogations to go forward. $^{34}$ It accomplished this by issuing a set of "self-applying regulations, ${ }^{n 35}$ or "bright-line" rules $^{36}$ for each police officer to follow during her custodial interrogation of citizens suspected of crimes. ${ }^{37}$ Moreover, it conserved the resources of the courts,

${ }^{30}$ See LeONARD W. LeVY, THE ORIGINS OF THE FIFTH AMENDMENT 330 (1968) ("To furnish testimonial evidence against himself, with or without oath, was likened to drawing one's blood, running oneself upon the pikes, or cutting one's throat with one's tongue."); 8 JOHN H. WIGMORE, EVIDENCE IN TRJALS AT COMMON LAW $\$ 2251$ at 317 (4th ed. 1961), revised by John T. McNaughton ("The privilege contributes toward a fair state-individual balance by requiring the government to leave the individual alone until good cause is shown for disturbing him and by requiring the government in its contest with the individual to shoulder the entire load.").

31 "[T] he American system of criminal prosecution is accusatorial, not inquisitorial, and the Fifth Amendment privilege is its essential mainstay. ... Governments, state and federal, are thus constitutionally compelled to establish guilt by evidence independently and freely secured, and may not by coercion prove a charge against an accused out of his own mouth." Malloy v. Hogan, 378 U.S. 1, 7-8 (1964) (citation omitted).

${ }^{32}$ See Murphy v. Waterfront Comm'n, 378 U.S. 52, 55 (1964) (discussing “our distrust of self-deprecating statements").

${ }^{3 s}$ See id. at 55 ("[S]elf-incriminating statements are likely to be elicited by inhumane treatment and abuses.").

${ }^{34}$ The Court devoted section IV of the Miranda opinion to a discussion of the needs of law enforcement. It noted that the FBI and police in other countries had been conducting successful interrogations after delivering warnings for years. See Miranda, 384 U.S. at $479-491$.

${ }^{95}$ Henry M. Hart \& Albert M. Sacks, The Legal Process: Basic Problems IN THE MAKING AND APPLICATION OF LAW 132-33 (tentative ed. 1958) (stating that a "self-applying regulation" is an official mandate that is "susceptible of correct and dispositive application by a person to whom it is initially addressed").

${ }^{36}$ The benefits of drawing bright-line rules for peace officers has been recognized by the Court and commentators. See, e.g., New York v. Belton, 453 U.S. 454, 458 (1981) (noting that "a single familiar standard is essential to guide police officers, who have only limited time and expertise to reflect on and balance the social and individual interests involved in the specific circumstances they confront") (quoting Dunaway v. New York, 442 U.S. 200, 213-14 (1979)); Albert W. Alschuler, Bright Line Fever and the Fourth Amendment, 45 U. PITT. L. REv. 227, 227 (1984) (noting that "[r]ules tend to limit the importance of subjective judgment, to promote equality, to control corruption, to simplify administration and to provide a basis for planning before and after controversies arise"); see also Wayne R. LaFave, The Fourth Amendment in an Imperfect World: On Drawing "Bright Lines" and "Good Faith," 43 U. PrTT. L. REv. 307, 321 (1982) (warning that "it may well be that the rules governing search and seizure are more in need of greater clarity than greater sophistication").

${ }^{37}$ The Court believed such limitation upon police conduct to be the only "assurance that practices of this nature [the unlawfully coercive tactics used during custodial interrogations prior to Miranda] will be eradicated in the foreseeable future." 
allowing the judiciary to monitor more closely these officer/citizen interactions by providing a model against which all custodial interrogations could be measured, rather than adjudicating each interaction on a case-by-case basis. ${ }^{38}$

While many passages in the decision assume the Miranda warnings have constitutional stature, the holding itself was a narrow one: statements obtained in violation of the warnings are inadmissible as part of the prosecutor's case-in-chief in a criminal trial against that defendant. ${ }^{39}$ The Court did appear to hold, however, that the Fifth Amendment applies at the station house ${ }^{40}$ and that the defendant must be apprised of his rights to prevent a violation of the Self-Incrimination Clause. ${ }^{41}$ The Miranda Court left open the possibility that Congress or the states could implement solutions aside from the prescribed warnings to ensure that the inherent compulsions of the custodial interrogation process would not produce coerced statements. ${ }^{42}$ But it was unclear whether this was

Miranda, 384 U.S. at 447.

${ }^{38}$ The drawbacks of the case-by-case approach in the confession context are best summarized by Charles J. Ogletree, Are Confessions Really Good for the Soul? A Proposal to Mirandize Miranda, 100 HARv. L. REV. 1826, 1833-35 (1987). In his article, Ogletree argued that the due process standard for determining the admission of confessions, which forced the Court to assess police conduct on a case-by-case basis, was inadequate because (1) it forced consideration of the innumerable methods of coercion and inducement employed by police, and the ways that such methods actually impact on the diverse group of suspects; (2) it did not provide the Court with the ability to direct the behavior of police; (3) it probably failed to allow the Court to guide lower courts and to grant relief in many instances involving coercive interrogations, given the small number of confession cases the Court could review each year; (4) it did not ensure that suspects knew their rights; and (5) it turned suppression hearings into a "swearing contest" as parties argued about confessions that occurred behind closed doors.

${ }^{39}$ See Miranda, 384 U.S. at 444 ("[T]he prosecution may not use statements, whether exculpatory or inculpatory, stemming from custodial interrogation of the defendant unless it demonstrates the use of procedural safeguards effective to secure the privilege against self-incrimination.").

${ }^{40}$ See id. at 467 ("[T]here can be no doubt that the Fifth Amendment privilege is available outside of criminal court proceedings ...." ).

${ }^{41}$ See id. at 468 ("[S]uch a warning is an absolute prerequisite in overcoming the inherent pressures of the interrogation atmosphere.").

${ }^{42} \mathrm{See} i \mathrm{~d}$. at 444 ("[U]nless other fully effective means are devised to inform accused persons of their right of silence and to assure a continuous opportunity to exercise it, the following measures are required."). Congress in fact attempted to do this by enacting the "Post Miranda Act." See 18 U.S.C. \$ 3501(b) (1989) (stating that the failure to give warnings is a factor to consider in determining the issue of voluntariness, but does not automatically exclude an otherwise voluntary confession); S. REP. No. 1097, 90th Cong., 2d Sess. 1968, reprinted in 1968 U.S.C.C.A.N. 2112, 2127 (noting that the Act was intended to offset "harmful" effects of certain Court 
because that particular method (the allocution of warnings) was not constitutionally required or because there was not necessarily a constitutional violation for which the selected method was to remedy. ${ }^{43}$

The Burger and Rehnquist Courts later interpreted the-Miranda holding as a mere prophylactic measure and made clear that a violation of Miranda does not equal a constitutional violation. ${ }^{44}$ For example, in Michigan v. Tucker, ${ }^{45}$ the defendant's statements were excluded at trial due to an incomplete Miranda warning, yet the trial judge admitted the testimony of a witness of whom the State became aware solely through the excluded statements of the defendant. ${ }^{46}$ The Court noted that:

Our determination that the interrogation in this case involved no compulsion sufficient to breach the right against compulsory selfincrimination does not mean there was not a disregard, albeit an inadvertent disregard, of the procedural rules later established in Miranda. The question for decision is how sweeping the judicially

decisions, including Miranda). This rule of admission, which requires no warnings or other mechanisms to ensure voluntariness, appears to me to fail to offer an "adequate" alternative safeguard. The Department of Justice has not found it appropriate to argue that voluntary statements taken in violation of Miranda be admitted pursuant to this statute. But cf. United States v. Crocker, 510 F.2d 1129, 1137-38 (10th Cir. 1975) (rejecting defendant's argument that the district judge erred in applying the more lenient standard of $\$ 3501$ and finding full compliance with Miranda and $\$ 3501$ constitutional).

${ }^{43}$ See Miranda, 384 U.S. at 467 ("[W]e cannot say that the Constitution necessarily requires adherence to any particular solution for the inherent compulsions of the interrogation process as it is presently conducted.").

${ }^{41}$ Numerous law professors have documented this event, some with remorse and others with pleasure. See, e.g., Joseph D. Grano, Introduction-The Changed and Changing World of Constitutional Criminal Procedure: The Contribution of the Department of Justice's Office of Legal Policy, 22 U. MiCH. J.L. REF. 395, 400-01 (1989) (noting that while Miranda was an extremely controversial decision, it is dogmatically accepted in most circles today, and urging the renewal of a balanced and vigorous debate concerning criminal procedure); Ogletree, supra note 38, at 1829 (noting that " [n]ot only do Miranda warnings fail to protect a suspect's right to silence and right to counsel, but the Supreme Court has substantially restricted Miranda's applicability, encouraging law enforcement authorities to be truly creative in developing novel strategies to circumvent the safeguards").

45417 U.S. 433 (1974).

${ }^{46}$ Defendant told police that during the night of the rape and assault in question he was with one Robert Henderson. However, this alibi backfired on the defendant when Henderson testified at trial that the defendant had left Henderson's company early on the night of the crime and that the defendant had scratches on his face the next morning. Noticing these scratches, Henderson asked the defendant "if he got hold of a wild one or something." The defendant answered that it was "some woman who lived the next block over." Id. at 436-37. 
imposed consequences of this disregard shall be. This Court said in Miranda that statements taken in violation of the Miranda principles must not be used to prove the prosecution's case at trial. That requirement was fully complied with by the state court here: respondent's statements, claiming he was with Henderson and then asleep during the time period of the crime were not admitted against him at trial. This Court has also said, in Wong Sun v. United States, 371 U.S. 471 (1963), that the "fruits" of police conduct which actually infringed a defendant's Fourth Amendment rights must be suppressed. But we have already concluded that the police conduct at issue here did not abridge respondent's constitutional privilege against compulsory self-incrimination, but departed only from the prophylactic standards later laid down by this Court in Miranda to safeguard that privilege. ${ }^{47}$

Miranda's standing even as a prophylactic rule has been undercut in a series of more recent cases. The deepest incision to date is the public safety exception, ${ }^{48}$ which permits a prosecutor to use, in his case-in-chief, statements taken in direct violation of the Miranda requirements. In New York $v$. Quarles, ${ }^{49}$ police officers pursued an armed robbery suspect into a supermarket, where he was frisked and found to be carrying an empty shoulder holster. After handcuffing the defendant, the pursuing officer asked him the location of the gun. After the defendant answered, the police officer retrieved the gun, formally arrested the defendant, and read

${ }^{47}$ Id. at 445-46 (emphasis added); see also Connecticut v. Barrett, 479 U.S. 523, 528 (1987) (discussing Miranda's rule that once an accused expresses his desire for an attorney the interrogation must cease until the attorney is present). The Barrett court stated that "this prohibition on further questioning-like other aspects of Miranda-is not itself required by the Fifth Amendment's prohibition on coerced confessions, but is instead justified only by reference to its prophylactic purpose." Id. The court went on to hold that the Constitution did not require suppression of defendant's incriminating statement where defendant, after Miranda warnings, stated his willingness to speak to police verbally, but expressed his unwillingness to make a written statement without the presence of counsel. See id. at 529; see also McNeil v. Wisconsin, 501 U.S. 171, 176 (1991) (stating that Miranda's warning requirement is not a dictate of the Fifth Amendment itself but a prophylactic rule); Michigan v. Harvey, 494 U.S. 344, 350 (1990) (same); Duckworth v. Eagan, 492 U.S. 195, 203 (1989) (same).

${ }^{48}$ Two states have enacted a similar exception, called the "rescue doctrine," which states that "exigent circumstances may excuse compliance with the Miranda rules in instances of overriding need to save human life or to rescue persons whose lives are in danger." People v. Riddle, 83 Cal. App. 3d 563, 574 (1978) (allowing police to interview a suspected kidnapper regarding location of victim), cert. denied, 440 U.S. 937 (1979); State v. Provost, 490 N.W.2d 93, 96-97 (Minn. 1992) (permitting police to question suspect in order to find burn victim), cert. denied, $113 \mathrm{~S}$. Ct. 1306 (1993).

49467 U.S. 649 (1984). 
him his Miranda rights from a printed card. The defendant then admitted buying the gun in Florida. The state trial court, as well as both state appellate courts, held that the original statement as to the location of the gun was to be excluded because the defendant was in custody and had not yet been given the warnings required by Miranda. The further statement regarding the place of purchase was excluded as evidence tainted by the prior Miranda violation. The Supreme Court reversed, finding that "this case presents a situation where concern for public safety must be paramount to adherence to the literal language of the prophylactic rules enunciated in Miranda.... [W]e conclude today that there are limited circumstances where the judicially imposed strictures of Miranda are inapplicable." ${ }^{50}$

Although the Court has not yet found other avenues to admit statements taken in violation of Miranda in the state's casein-chief, it has recently offered numerous other ways that such statements can be utilized. Statements taken in violation of Miranda can be used to obtain other leads, ${ }^{51}$ for impeachment, ${ }^{52}$ for rebuttal of an insanity defense, ${ }^{53}$ and at senten-

${ }^{50} \mathrm{Id}$. at $653 \& \mathrm{n} .3$. The relevant circumstances were the combination of the danger presented by the gun, which was concealed somewhere in a public supermarket where a customer, employee, or accomplice might make use of it, with the possibility that the Miranda warnings would deter Quarles from responding to the officer's question about the location of the gun. See id. at 657. The Court noted that there was no claim that the defendant's statements were "actually compelled" by police conduct, id. at 654 (emphasis added), and reminded defendant that he was "free on remand to argue that his statement was coerced under traditional due process standards." Id. at 655 n.5.

${ }^{51}$ See Michigan v. Tucker, 417 U.S. 433, 445-46 (1974) (noting that Wong Sun does not apply to exclude evidence obtained as a result of an inadvertent disregard of Miranda where the underlying police conduct infringes a nonconstitutional prophylactic rule only).

${ }^{52}$ See, e.g., Oregon v. Hass, 420 U.S. 714, 716-18 (1975) (holding that statement taken by a police officer who questioned a defendant after he requested an attorney, but before the attorney could be contacted, can be used at a criminal trial to impeach such defendant, should he take the stand); Harris v. New York, 401 U.S. 222, 224 (1971) (holding that statements taken from defendant without informing him of his right of access to appointed counsel could be used to impeach the defendant's direct testimony at trial provided that the trustworthiness of such statements satisfies legal standards).

${ }^{53}$ A prosecutor may not, however, use defendant's silence after Miranda warnings as evidence of his sanity. See Wainwright v. Greenfield, 474 U.S. 284 (1986) (holding that the prosecutor's use of respondent's post-arrest, post-Miranda warnings silence as evidence of sanity violates the Due Process Clause). Nor may a prosecutor use statements taken in a court-ordered psychiatric examination where the Miranda warnings were not delivered and waived. See Estelle v. Smith, 451 U.S. 454 (1981) 
cing. ${ }^{54}$ An initial unwarned confession does not "taint" a subsequent confession made after proper Miranda warnings. ${ }^{55}$ Criminal convictions will not be overturned despite the admission of a confession taken in violation of an accused's Miranda rights if the government establishes harmless error. ${ }^{56}$ Finally, in a bold and sudden move dislodging years of tradition, Chief Justice Rehnquist, writing for a five-justice majority, held that a violation of the SelfIncrimination Clause itself does not require a new trial if that error was "harmless."

(holding that the admission of doctor's testimony violated the respondent's privilege against self-incrimination because he was not advised of his right to remain silent before the psychiatric evaluation).

54 Although the United States Supreme Court has not yet spoken on this issue, a number of federal appellate courts have. See, e.g., United States v. Rojas-Martinez, 968 F.2d 415, 421-22 (5th Cir. 1992) (finding co-conspirators' confessions inadmissible at trial but admissible at sentencing to determine whether or not defendant was an organizer), cert. denied, 113 S. Ct. 995 (1993); United States v. Smith, 909 F.2d 1164,1168 (8th Cir. 1990) (holding the use of post-arrest statements at sentencing does not violate defendant's right to due process), cert. denied, 498 U.S. 1032 (1991).

${ }^{55}$ See Oregon v. Elstad, 470 U.S. 298, 303-04 (1985) (noting that unlike a violation of the Fourth Amendment, where the "fruit of the poisonous tree" doctrine requires exclusion of derivative evidence, a mere Miranda violation does not violate the Fifth Amendment and thus does not require that fruits of an otherwise voluntary statement be discarded as inherently tainted).

${ }^{36}$ A number of federal appellate courts have held that the introduction of incriminating statements taken from defendants in violation of Miranda is subject to treatment as harmless error. See Howard v. Pung, 862 F.2d 1348, 1351 (8th Cir. 1988) (finding that any error in admitting a confession made by the defendant after his equivocal request for counsel was harmless due to the other overwhelming evidence against the defendant), cert. denied, 492 U.S. 920 (1989); United States v. Ramirez, 710 F.2d 535, 542-43 (9th Cir. 1983) (finding that the district court erred in admitting testimony consisting of inculpatory statements prior to establishing that the defendant had waived his Miranda rights, but holding that the error was harmless in view of evidence showing conclusively that the defendant did indeed waive his rights under Miranda).

${ }^{57}$ See Arizona v. Fulminante, 111 S. Ct. 1246, 1263-65 (1991). Chief Justice Rehnquist was joined by Justices Kennedy, O'Connor, Scalia, and Souter in holding that the introduction of a coerced confession, in violation of due process, is a "trial error" rather than a "structural defect" and thus subject to harmless error analysis. This holding represents a 180 degree departure from almost one hundred years of tradition and case law, from Bram v. United States, 168 U.S. 532, 565 (1887) (holding that an improperly admitted coerced confession mandates new trial), to Chapman v. California, 386 U.S. 18, 24-26 (1967) (concluding that although certain constitutional errors may be harmless, the rule against coerced confessions is so basic to a fair trial that its violation warrants automatic reversal of the resulting conviction). For a further discussion of the effects of this case, see, for example, People v. Cahill, 853 P.2d 1037, 1060 (Cal. 1993) (Most, J., dissenting) (stating that the majority opinion, which relies on Fulminante, "send[s] us back to the Inquisition and the Star Chamber"); Charles J. Ogletree, Jr., Arizona v. Fulminante: The Harm of Applying 
Miranda's existence is threatened by this consistent attack at and erosion of its borders. The Court's constant pronouncements, over the years, that Miranda lacks constitutional exegesis have subjected the Court to the grave but logically compelling argument that it lacked authority to deliver the rule in the first place. In arguing for Miranda's reversal, a number of commentators and the pre-Reno Department of Justice have forcefully argued that the Court has no authority, pursuant to Article III, Section 2 of the U.S. Constitution, ${ }^{58}$ to overturn a state court criminal conviction absent a federal constitutional violation..$^{59}$

The Court recently had this issue squarely before it, but chose to sidestep the problem. In Withrow $v$. Williams, ${ }^{60}$ the Court refused to extend Stone $v$. Powell' $\mathrm{s}^{61}$ restriction on the exercise of federal habeas jurisdiction in Fourth Amendment cases to bar a state prisoner's Fifth Amendment claim that his conviction rested on statements taken in violation of Miranda's safeguards. The

Harmless Error to Coerced Confessions, 105 HARV. L. REV. 152, 161 (1991) (critiquing the Court's harmless error analysis, especially its insufficient recognition of certain values in the criminal justice system).

${ }^{58}$ See U.S. CONST. art. III, $\$ 2$ ("The judicial Power shall extend to all Cases, in Law and Equity, arising under this Constitution, The Laws of the United States, and Treaties made, or which shall be made, under their Authority ....").

${ }^{59}$ See, e.g., DEPARTMENT OF JUSTICE REPORT, supra note 7, at 443 (recommending that the Department seek to persuade the Supreme Court to abrogate or overrule Miranda because the decision is inconsistent with the constitutional separation of powers, has an adverse effect on the government's ability to protect the public from crime, and is inadequate as a means of ensuring fair treatment of suspects in custodial questioning); Grano, supra note 44, at 405 (noting that the Report challenges the constitutional legitimacy of the Supreme Court's imposition of rules upon the states that the Court concedes are not constitutionally mandated); Joseph D. Grano, Miranda's Constitutional Difficulties: A Reply to Professor Schulhofer, 55 U. CHI. L. REv. 174, 187 (1988) [hereinafter Grano, Constitutional Difficulties] (arguing that Professor Schulhofer's failure to explain the source of the Supreme Court's authority to impose prophylactic rules leaves the Miranda decision open to a challenge of illegitimacy); Joseph D. Grano, Prophylactic Rules in Criminal Procedure: A Question of Article III Legitimacy, 80 Nw. U. L. REv. 100, 102-03 (1985) [hereinafter Grano, Prophylactic Rules] (arguing that prophylactic rules are not justified by federal common law as an implied power of the Judiciary or as an implication of federal question jurisdiction); Stephen J. Markman, The Fifth Amendment and Custodial Questioning: A Response to "Reconsidering Miranda," 54 U. CHI. L. REV. 938, 938 (1987) (defending the findings of the Department of Justice Report, which was prepared under his direction in his capacity as Assistant Attorney General for Legal Policy).

60113 S. Ct. 1745 (1993), cert. denied, 114 S. Ct. 882 (1994).

${ }^{61} 428$ U.S. $465,481-82$ (1976) (holding that federal habeas review of allegations that a conviction rests on evidence obtained through an unconstitutional search or seizure is unavailable when a state has given the defendant a full and fair chance to litigate a Fourth Amendment claim). 
Department of Justice argued that since Miranda's prophylactic safeguards are not guaranteed by the Federal Constitution or federal statute, habeas review should not extend to claims based upon the absence of such safeguards. ${ }^{62}$ The majority, however, rather than confronting this difficult constitutional issue, merely noted that

tension results between the [federal and state] judicial systems whenever a federal habeas court overturns a state conviction on finding that the state court let in a voluntary confession obtained by the police without the Miranda safeguards.... It is not reasonable, however, to expect such occurrences to be frequent enough .... to raise federal-state tensions to an appreciable degree. ${ }^{63}$

Likewise, one dissenting opinion argued that Miranda is a judicially created remedy, as opposed to a "true Fifth Amendment" claim, ${ }^{64}$ but assumed without discussion that the Court had authority to hear the claim, arguing against it on the bases of equity and judicial administration.

Justice Souter's purported reasoning notwithstanding, ${ }^{65}$ the

${ }^{62}$ See Withrow, 113 S. Ct. at 1752 (citing Brief for United States as Amicus Curiae at 14-15) (examining the Court's conclusion that habeas review should not extend to a claim that a state conviction rests on statements obtained in the absence of Miranda's safeguards because those safeguards are not constitutional but merely prophylactic). A violation of federal common law would also support a habeas corpus petition, and arguably could be the basis of a $\S 1983$ suit. The Court, however, has never held that Miranda is a product of federal common law. For a variant of this position, see infra part III.C.

${ }^{63} \mathrm{Id}$. at $1754-55$ (five-justice majority).

${ }^{64}$ See id. at 1758-60 (O'Connor, J., concurring in part and dissenting in part) (noting that the question is whether violations of Miranda's prophylactic rules, which are not true Fifth Amendment claims, should be cognizable on habeas review). The argument that there should be no habeas because "there is no constitutional harm to remedy," id. at 1761 , applies equally to the Supreme Court's authority to review a Miranda violation on direct appeal via a petition for certiorari.

${ }^{65}$ The Court's holding was based on the perceived differences between the Fourth Amendment's exclusionary rule as outlined in Mapp v. Ohio, 367 U.S. 643 (1961) and the Fifth Amendment's exclusionary rule articulated in Miranda v. Arizona, 384 U.S. 436 (1966). In contrast to $M a p p$, the Court held that Miranda safeguards a fundamental trial right in protecting a defendant's privilege against self-incrimination and facilitates the correct ascertainment of guilt by guarding against the use of unreliable statements at trial. The Court also stated that refusing jurisdiction would not advance the cause of federalism or ease the burdens on the federal court, as every barred Miranda claim would resurface as a due process voluntariness claim. See Withrow, 113 S. Ct. at 1755 ("We thus fail to see how abdicating Miranda's bright-line rules ... would do much of anything to lighten burdens placed on busy federal courts."). 
Court actually ruled as it did because otherwise there would be no federal court review, aside from a direct appeal from the highest state court to the U.S. Supreme Court via a certiorari petition, to ensure that state courts and police followed the dictates of Miranda. ${ }^{66}$ The Court realized the general danger of promulgating unenforced prophylactic rules and the specific danger to the privilege against self-incrimination posed by unwarned custodial interrogations but was unwilling or unable to come to grips with the tougher and more divisive issue regarding its actual authority. Resolving this issue, in my opinion, requires either overruling Miranda or reconstitutionalizing it.

The Justice Department and the Court have sidestepped this same issue arising in a different context by refusing to rule on the constitutionality of 18 U.S.C. $\$ 3501(a)$, an unused federal statute enacted in 1968, which calls for admissions of confessions in federal court cases if voluntary, regardless of whether Miranda-type warnings were given. ${ }^{67}$ The Department of Justice under President Clinton specifically declined to raise this statute in a case last term concerning a statement admitted in a United States Court of Military Appeals, allegedly in violation of a sailor's Miranda rights. ${ }^{68}$ In a concurring opinion, Justice Scalia announced his intention, in the next federal case involving a confession, to rule on this statute's constitutionality, regardless of whether the Executive chose to invoke it. ${ }^{69}$ If the Department should choose to advance

${ }^{66}$ While the Court noted that Miranda's bright-line rule lightens the burden on busy federal courts by guiding police behavior and acknowledged that law enforcement is generally willing and able to satisfy Miranda's requirements, it admitted that there remains a need for federal collateral review of Miranda's requirements, since "the respect [of law enforcement for constitutional guarantees] is sustained in no small part by the existence of such review." Withrow, $113 \mathrm{~S}$. Ct. at 1754-55.

${ }^{67}$ See supra note 42 . This statute provides that "in any criminal prosecution brought by the United States . . . a confession ... [is] admissible in evidence if it is voluntarily given." 18 U.S.C. $\$ 3501$ (a). In determining the issue of voluntariness, the judge shall consider all circumstances, including "(3) whether or not such defendant was advised or knew that he was not required to make any statement and that any statement could be used against him, (4) whether or not such defendant had been advised prior to questioning of his right to the assistance of counsel." Id.

${ }^{68}$ See Davis v. United States, 114 S. Ct. 2350, 2354 n.* (1994) ("We also note that the Government has not sought to rely in this case on 18 U.S.C. $\$ 3501 \ldots$ and we therefore decline the invitation of some amici to consider it.").

${ }^{69}$ Justice Scalia stated,

I am entirely open to the argument that $\$ 3501$ does not mean what it appears to say; that it is inapplicable for some other reason; or even that it is unconstitutional. But I will no longer be open to the argument that this Court should continue to ignore the commands of $\S 3501$ simply because 
this statute, or if Justice Scalia can convince a majority of other Justices to rule on the statute despite the Department's wishes, the question of Miranda's pedigree will soon be forced upon the Court.

\section{B. Impossibility of Enforcing the Fifth Amendment via § 1983 Actions}

Given the Court's current interpretation of the Miranda decision, a violation of its safeguards should not constitute the basis of a $\S 1983$ action. Since the Miranda warnings are not themselves constitutional mandates, it follows a fortiori that a failure to adhere to them cannot constitute a constitutional violation. Without a violation of the Federal Constitution or federal statutes, a $\$ 1983$ claim is groundless. ${ }^{70}$ Moreover, the combination of various Court decisions concerning doctrines associated with civil rights actions has made it virtually impossible to successfully bring a $\S 1983$ action for a violation of the Self-Incrimination Clause. The vast majority of courts hearing the issue have held that a Miranda violation is not a proper basis for a $\S 1983$ claim. A few courts have denied summary judgment for the defendants in such suits, however, based upon rather strained readings of Court opinions.

\section{Gases Denying a $\S 1983$ Action}

In what some commentators have characterized as outright hostility to $\S 1983$ lawsuits, ${ }^{71}$ courts have developed a myriad of legal and policy arguments to justify the dismissal of such actions, finding no constitutional violation, invoking prosecutorial immunity, finding that the official did not act under color of state law, or all three. ${ }^{72}$

the Executive declines to insist that we observe them.

Id. at 2358.

${ }^{70}$ See, e.g., Maine v. Thiboutot, 448 U.S. 1, 4-6 (1980) (holding that $\$ 1983$ creates a cause of action against state officials for purely statutory violations of federal law); Carey v. Piphus, 435 U.S. 247, 254-57 (1978) (noting that the basic purpose of a $\$ 1983$ damage award is "to compensate persons for injuries caused by a deprivation of constitutional rights").

${ }^{71}$ See, e.g., Jack M. Beermann, A Critical Approach to Section 1983 with Special Attention to Sources of Law, 42 STAN. L. REv. 51, $52-53$ (1989) (arguing that legal and policy arguments of courts, as well as the manipulation of the text and legislative history of the statute, are a smokescreen to hide the conservative, political ideology of the judges).

72 See, e.g., Triplett v. Azordegan, 570 F.2d 819 (8th Cir. 1978). Ernest Triplett was arrested, involuntarily committed to a mental hospital, and given large doses of the drugs desoxyn and seconal by a staff physician at the institution. Shortly thereafter, Triplett confessed to a murder, and his confession was taped. The prosecutor, 
In the area of confessions, four dominant methods have emerged.

\section{a. A Miranda Violation Is Not a Constitutional One}

The most direct method is simply to state that a Miranda violation is not a violation of the Federal Constitution and thus cannot form the basis of $\S 1983$ liability. This argument has a compelling simplicity and logical appeal, and has been adopted by numerous federal courts as a justification for dismissing $\S 1983$ suits in cases involving an officer's failure to adequately Mirandize a suspect. For example, in Bennett v. Passic, ${ }^{73}$ the Tenth Circuit held in no uncertain terms that failure to give Miranda warnings cannot subject a police officer to liability under the Civil Rights Act. Plaintiff Howard Smith Bennett was arrested and then incarcerated in the drunk tank of the city jail for about one hour when Deputy Sheriff Adams discovered one of Bennett's cellmates in a pool of blood. Adams testified at Bennett's criminal trial that upon questioning, Bennett replied, "I killed the son-of-a-bitch because he wouldn't shut up. "74 After Bennett was convicted of murder, he instituted a civil suit against the Sheriff and various state and local law enforcement officials alleging, inter alia, that he was not warned of

Donald O'Brien, obtained the taped confession by means of an Iowa state court order. After it was determined that the murder occurred in Plymouth County rather than Woodbury County, the case was transferred to two other prosecutors. In June of 1955, the Plymouth County prosecutors played the taped confession for the jury, and Triplett was convicted of murder. Triplett later brought a federal habeas corpus action. The court held that Triplett's conviction was obtained in violation of due process and ordered an evidentiary hearing. The Plymouth County court ruled that the confession was given involuntarily and ordered Triplett's release in October of 1972,17 years after his conviction. See id. at 821-22.

Triplett then commenced a civil action against prosecutor O'Brien pursuant to $\S 1983$, which the district court dismissed on the ground of prosecutorial immunity. The appellate court affirmed on the ground that Triplett failed to state a claim upon which relief could be granted. See id. at 822. O'Brien's procurement of the tape constituted no violation of appellant's constitutional rights since he acted under protection of a court order. See id. at n.3. Likewise, O'Brien did not use the confession in such a way as to deprive appellant of his constitutional rights because O'Brien did not prosecute the case, and O'Brien did not conceal or withhold information from the prosecutors who did. See id. at 823 . Furthermore, O'Brien's failure to come forward with exculpatory information at appellant's trial or thereafter was not an act under color of state law and therefore could not serve as the basis of a $\$ 1983$ action. See id. at 824.

73545 F.2d 1260, 1263 (10th Cir. 1976).

"Id. at 1262. 
his Miranda rights prior to the custodial interrogation concerning the murder. ${ }^{75}$

The district court denied Bennett's motion to proceed with his $\S 1983$ action on the ground that the action was frivolous, and the appellate court affirmed. ${ }^{76}$ In responding to the charge that Adams's failure to warn Bennett of his Miranda rights violated the Fifth Amendment, the court noted that even assuming Bennett's confession should have been excluded from evidence at his trial, there was no basis for a civil rights claim for damages:

The Constitution and laws of the United States do not guarantee Bennett the right to Miranda warnings. They only guarantee him the right to be free from self-incrimination. The Miranda decision does not even suggest that police officers who fail to advise an arrested person of his rights are subject to civil liability; it requires, at most, only that any confession made in the absence of such advice of rights be excluded from evidence. ${ }^{77}$

The Eighth Circuit extended this analysis to instances in which the defendant's invocation of the rights supposedly secured by Miranda was not honored. In Warren $v$. City of Lincoln,${ }^{78}$ plaintiff Jackson Warren appealed certain dismissals and jury verdicts for

${ }^{75}$ See id.

${ }^{76}$ See id. at 1264 .

${ }^{77}$ Id. at 1263. For a factually similar case reaching the identical decision, see, for example, Williams v. Tansey, 610 F. Supp. 1083, 1085 (E.D. Pa. 1985). The plaintiff in Williams filed a $\$ 1983$ action, alleging that two police detectives arrested him because of his interracial marriage, searched his house and seized belongings without a search warrant, failed to provide Miranda warnings, refused his request to be placed in a lineup, and perjured themselves in his criminal trial. The district court granted the defendants' motion to dismiss, reasoning that since the warnings required by Miranda are not constitutional rights but measures designed to protect against compulsory self-incrimination, failure to give warnings did not subject the detectives to $\$ 1983$ liability. See also Thornton v. Buchmann, 392 F.2d 870, 874 (7th Cir. 1968) (holding that statements made by a defendant who had not been Mirandized would be inadmissible at trial but finding no violation of the defendant's constitutional rights); Turner v. Lynch, 534 F. Supp. 686, 689 (S.D.N.Y. 1982) (dismissing plaintiff's $\$ 1983$ claim against two police officers who allegedly failed "to adhere to the established principles of the Miranda warning" and holding that plaintiff's sole remedy was exclusion of evidence at trial); Hampton v. Gilmore, 60 F.R.D. 71, 81 (E.D. Mo.), aff d, 486 F.2d 1407 (8th Cir. 1973) ("The Constitution . . . nowhere provides that an individual has the right to be warned of his constitutional rights" and that failure to warn results only in the inadmissibility of evidence at trial); Ambrek v. Clark, 287 F. Supp. 208 (E.D. Pa. 1968) (stating that "the sole import" of a failure to Mirandize is the exclusion of evidence at trial); $c f$. Hensley v. Carey, 818 F.2d 646, 649-50 (7th Cir.), cert. denied, 484 U.S. 965 (1987) (holding that failure to conduct a lineup does not create liability under $\S 1983)$.

78864 F.2d 1436 (8th Cir.) (en banc), cert. denied, 490 U.S. 1091 (1989). 
the defendants in his $\S 1983$ action against the City of Lincoln, Nebraska and three Lincoln police officers, based upon an allegedly unlawful arrest and Miranda violation. Police officers responded to a call from "a man who claimed someone had just attempted to break into his apartment," describing the intruder as "a slender white male in his early twenties wearing a white short-sleeved shirt."79 An officer with a police dog tracked the intruder's scent to Warren's parked car four and one-half blocks from the crime scene. Warren, a slender, white, nineteen-year-old male wearing a light-colored, short-sleeved shirt, attempted to drive away when the police officer approached. Another officer flagged Warren down and ran a check on his license. She discovered an outstanding warrant for Warren for failure to appear on a traffic violation and arrested him on this charge. The officer took Warren to the Lincoln jail complex, where he was interrogated by a detective concerning a series of burglaries and sexual assaults that resembled the attempted burglary. The detective denied Warren's requests to see an attorney and neither he nor any other Lincoln police officer read Warren his Miranda rights. ${ }^{80}$

The en banc panel affirmed the judgment of the district court, holding that the officers' failure to read Warren the Miranda warnings and the detective's denial of Warren's requests to see counsel did not constitute a viable basis for a $\S 1983$ action. According to the court, the Miranda warnings are merely "a procedural safeguard rather than a right arising out of the [F]ifth [A]mendment itself," and thus the sole remedy for a Miranda violation is the exclusion from evidence of any self-incriminating statement. ${ }^{81}$

${ }^{79}$ Id. at 1437.

${ }^{80}$ See id. at 1438.

${ }^{81} \mathrm{Id}$. at 1442. The court in Chrisco v. Shafran, 507 F. Supp. 1312 (D. Del. 1981) reached a similar conclusion. The plaintiff, willie Chrisco, a former officer of the Wilmington Police Department, brought a civil rights action against Carl Williams, a Delaware State Police Officer, and Milton Shafran, a former Delaware Deputy Attorney General, for alleged violations of his constitutional rights during the course of an internal investigation. After Williams and Shafran interviewed Chrisco on six different occasions for periods of up to eight hours per meeting, a plea agreement was reached which resulted in Chrisco's reduction of rank to patrolman with no criminal charges filed. See id. at 1314. Chrisco alleged, inter alia, that he was prevented from leaving during the final interrogation session, was not given Miranda warnings, and was not permitted to have an attorney present or to discuss the conversations with his attorney. See id.

The court held that these allegations, standing alone, did not give rise to a damages action for violation of the Fifth Amendment because "the right to Miranda warnings and the right to have counsel present during custodial interrogation are not 
The Warren-type cases, ${ }^{82}$ however, can be distinguished from the Bennett-type cases. ${ }^{83}$ In the latter cases, the police failed to warn the defendants of their Miranda rights, whereas in Warren the police outright refused to honor the defendant's request to speak to an attorney. The Warren court, however, having already held that there was no Fifth Amendment right to an attorney stemming from Miranda, held that there had been no Sixth Amendment violation because the right to counsel had not yet attached. ${ }^{84}$ Although the reasoning used by the Warren court logically flows from the reasoning used by courts in failure-to-warn cases, there is something particularly unseemly and disturbing about its extension. One can excuse the state action in the failure-to-warn cases as the product of forgetfulness or negligence. But when the police warn a suspect of her Miranda rights and then refuse to abide by their own recitation of these rights, it is impossible to ascribe an innocent motive to their conduct.

The consequence of a court's holding that a Miranda violation is not a constitutional violation is that a plaintiff in a civil rights case must prove that her confession was actually involuntary in the due process sense. A failure to deliver Miranda warnings, or even a failure to honor a suspect's invocation of these rights, does not necessarily or even generally establish that her will was overcome.

independent constitutional rights. Rather, they are 'procedural safeguards ... devised to inform accused persons of their right of silence and to assure a continuous opportunity to exercise it ....' Id. at 1317 (citation omitted). As to Chrisco's rightto-counsel claim, the court held that there was no Sixth Amendment violation because no judicial proceedings had yet begun. See id. at 1320 . Thus if Chrisco had a right to counsel during questioning, it stemmed from the Fifth Amendment procedural safeguards required by Miranda. But Miranda recognizes a right to counsel during custodial interrogation only because the presence of counsel is "the adequate protective device necessary to make the process of police interrogation conform to the dictates of the privilege. [Th]is presence would insure that statements made in the government-established atmosphere are not the product of compulsion." Miranda v. Arizona, 384 U.S. 436, 466 (1966). Thus the Chrisco court concluded that "[f]or the same reasons that there is no action for damages for failure to advise of Miranda warnings, there can be no civil action for denying access to counsel during custodial interrogation." Chrisco, 507 F. Supp. at 1321.

${ }^{82}$ See supra notes 78-81 and accompanying text.

ss See Bennett v. Passic, 545 F.2d 1260 (10th Cir. 1976); supra note 77 and accompanying text.

${ }^{8}$ See Warren, 864 F.2d at 1442 (noting that Warren was never subjected to criminal proceedings, which might require legal representation). 


\section{b. The Fifth Amendment Can Only be Violated in Court}

Assuming that a case involved actual and not presumed compulsion, a court must still answer the question of when a Fifth Amendment violation can occur before permitting a $\$ 1983$ action to go forward. Although Miranda briefly extended the protection of the Fifth Amendment to the station house, historically, the privilege has applied only to courtroom or congressional testimony given under oath. ${ }^{85}$

The Supreme Court has definitively resolved this timing issue in two cases. In Kastigar $v$. United States, ${ }^{86}$ the Court held that the government may compel an individual to speak, consistent with the Fifth Amendment, so long as it does not use the results against him in a criminal proceeding. Thus actual compulsion does not by itself violate the Fifth Amendment. In United States v. Verdugo-Urquidez, ${ }^{87}$ the Court held that the Fourth Amendment did not apply to the search and seizure by DEA agents of property owned by a nonresident alien defendant and located in the Republic of Mexico. The Court explained why the alien was nevertheless entitled to trialrelated rights guaranteed by the Fifth and Sixth Amendments. According to Justice Rehnquist, a Fourth Amendment violation is fully accomplished at the moment when the unreasonable search occurs. Since this unreasonable search occurred outside the U.S. against a noncitizen, the Fourth Amendment was never implicated. The Court noted, albeit in dicta, that the Fourth Amendment

operates in a different manner than the Fifth Amendment, which is not at issue in this case. The privilege against self-incrimination guaranteed by the Fifth Amendment is a fundamental trial right of criminal defendants. Although conduct by law enforcement officials prior to trial may ultimately impair that right, a constitutional violation occurs only at trial. ${ }^{88}$

${ }^{85}$ The privilege against self-incrimination has been held applicable in various proceedings. See, e.g., In re Gault, 387 U.S. 1 (1967) (holding the privilege applicable in juvenile proceedings); Malloy v. Hogan, 378 U.S. 1 (1964) (statutory proceeding); Watkins v. United States, 354 U.S. 178 (1957) (congressional investigations); McCarthy v. Arndstein, 266 U.S. 34 (1924) (civil proceedings); Counselman v. Hitchcock, 142 U.S. 547 (1892) (grand jury proceedings). These cases all involved sworn testimony in a judicial or quasi-judicial tribunal. Such testimony would be admissible in a subsequent criminal trial.

${ }^{86} 406$ U.S. $441,448-49$ (1972) (holding that the government's grant of immunity to a defendant preventing the use and derivative use of a compelled statement in a subsequent criminal trial is coextensive with the privilege against self-incrimination).

${ }^{87} 494$ U.S. 259 (1990).

${ }^{88}$ Id. at 264 (citation omitted). 
A number of courts have reached similar conclusions in the $\S 1983$ context. For example, in Davis $v$. City of Charleston, ${ }^{89}$ the court held that police officers' failure to give Miranda warnings did not deprive a suspect of his constitutional rights because the statements obtained during custodial interrogation were not used against him at trial. Likewise, in Ransom v. City of Philadelphia, ${ }^{90}$ the court held that

unless and until some use is made of an illegally obtained confession in such a way as to deprive a person of constitutional rights, no claim is stated under the Civil Rights Act. Plaintiff may have to await the outcome of his state court criminal proceedings before he may base a claim upon the allegedly improperly obtained confession. ${ }^{91}$

These two bars on a $\S 1983$ action based upon a Miranda violation-that such a violation is not a constitutional one and that the Self-Incrimination Clause can be violated only in a criminal proceeding-were recently combined in a Ninth Circuit opinion. In Cooper v. Dupnik, ${ }^{92}$ plaintiff Clarence Cooper brought a $\S 1983$

${ }^{89} 827$ F.2d 317, 322 (8th Cir. 1987), rev'd, 917 F.2d 1502 (8th Cir. 1990) (reversing only the award of attorney's fees to police officers).

${ }^{90} 311$ F. Supp. 973 (E.D. Pa. 1970).

${ }^{91} I d$. at 974 . After reaching this conclusion, the court granted judgment on the pleadings to the defendants. See id.; see also Chrisco v. Shafran, 507 F. Supp. 1312, 1321 (D. Del. 1981). The Chrisco court held that the defendant's due process right against use of his involuntary statement comes into play only in the context of a criminal prosecution. See id. at 1318. Thus, the court held that unlike Fourth or Sixth Amendment cases, in the Fifth Amendment context the exclusion of the incriminating statements is itself the constitutional right, not the remedy for a constitutional violation. See id. at 1317.

Professor Arnold Loewy suggests not only that a Miranda violation can never provide the basis for a $\$ 1983$ action but that sound public policy may dictate that police be permitted to choose not to provide Miranda warnings or to ignore the warnings they give. See Arnold H. Loewy, Police-Obtained Evidence and the Constitution: Distinguishing Unconstitutionally Obtained Evidence From Unconstitutionally Used Evidence, 87 MICH. L. REV. 907, 922-23 (1989). Loewy posits that the Miranda doctrine mandates exclusion of evidence not because the evidence was unconstitutionally obtained and exclusion is desirable to deter police behavior, but because the defendant has a procedural right to its exclusion at trial. See id. at 917 . Thus, "courts should not care whether or not Miranda is violated so long as no evidence obtained from the violation is introduced against the person from whom it was obtained. Similarly, no police officer should be subject to a law suit for obtaining a confession in violation of Miranda." Id.

${ }_{92} 924$ F.2d 1520 (9th Cir. 1991) [hereinafter Cooper I], rev'd en banc, 963 F.2d 1220 (9th Cir.), cert. denied, 113 S. Ct. 407 (1992) [hereinafter Cooper II].

The Honorable Cynthia Holcomb Hall wrote the original panel's decision in Cooper I. The author served as a judicial law clerk for Judge Hall at that time. The 
action $^{93}$ against the Pima County Sheriff's Department and the Tucson Police Department alleging, inter alia, a violation of his Fifth Amendment right against compulsory self-incrimination and his Fourteenth Amendment right to substantive due process. ${ }^{94}$

A series of rapes, robberies, and kidnappings had occurred from 1984 to 1986 in the Tucson area. ${ }^{95}$ These crimes received considerable media attention; the suspect was dubbed the "Prime Time Rapist." ${ }^{\text {96 }}$ A joint task force of the Tucson Police Department and the Pima County Sheriff's Department determined prior to Cooper's arrest that they would continue to question any suspect in this particular case despite his request for silence or for an attorney. ${ }^{97}$ In fact, there was evidence that these two law enforcement agencies had been disregarding defendants' requests for counsel, at their discretion, since $1981 .^{98}$

Cooper was arrested after a Tucson Police Department identification technician reported (orally) that two sets of latent prints found at the scenes of two of the Prime Time Rapist's crimes were identified as belonging to Cooper. ${ }^{99}$ The head of the police department's identification laboratory later rescinded this report, admitting that it was incorrect. ${ }^{100}$ The officers Mirandized Cooper

opinions expressed in this Article do not necessarily reflect the opinions of Judge Hall.

${ }^{93}$ Cooper additionally alleged nine counts under state tort law, including false arrest, malicious prosecution, defamation, false-light invasion of privacy, intentional infliction of emotional distress, trespass, conversion, negligence, and conspiracy. See Cooper I, 924 F.2d at 1525 n.4. These state law claims were dismissed, and were not at issue in the federal appeal.

${ }^{94}$ Cooper also brought a federal action for defamation, which was held proper by the original panel and en banc court. See id. at 1535-37; Cooper II, 963 F.2d at 1235. Finally, Cooper brought $\$ 1983$ counts for false arrest, false imprisonment, and improper training and procedures, which the district court upheld in a summary judgment proceeding against the appellants' assertions of qualified immunity. The ruling on those counts was not appealed by the Pima County or City of Tucson appellants. See Cooper I, 924 F.2d at 1525 \& n.5.

${ }^{95}$ See Cooper I, 926 F.2d at 1523.

${ }^{96}$ See id.

${ }^{97}$ See id. The police later explained that this decision was based on a psychological profile indicating that the rapist was "con-wise," and would demand an attorney during an interrogation. Id. n.I.

${ }_{93}$ See id. at 1523-24. Officers from these agencies understood that statements obtained in violation of Miranda would be inadmissible in a criminal trial. They believed, however, that such statements might be held voluntary and thus could be used to impeach the defendant, to keep him off the stand, or to deprive him of an insanity defense. See id. at 1524.

${ }^{99}$ See id.

${ }^{100}$ See id. The technician later admitted to his superior that he had not done a 
at his probation office and conducted a pre-arrest interview. During this interview, the officers told Cooper that his prints matched those found at the scenes of the two crimes, which they believed to be true, and that his prints matched those found at another Prime Time Rapist crime scene, which they knew to be false. ${ }^{101}$ After half an hour, the officers placed Cooper under arrest. He then made his first unequivocal request to speak to his attorney. ${ }^{102}$ The officers denied this request. ${ }^{103}$

Cooper was transported to the Pima County Sheriff's Department where he was interrogated for approximately four hours by Detective Wright of the Tucson Police Department and Detectives Barkman and Hust of Pima County. ${ }^{104}$ All participating officers were aware that Cooper had requested an attorney and that they were violating Miranda in refusing to honor that request. ${ }^{105}$ During the interrogation "Cooper was visibly upset, sometimes angry and crying. ${ }^{106}$ Detective Barkman made certain derogatory references to Cooper's Judaic background and questioned him about his sexual practices with his wife. ${ }^{107}$

Cooper was booked into the Pima County Jail that evening. ${ }^{108}$ He made another request for counsel, which was again ignored. ${ }^{109}$ Thus, Cooper had no contact with either an attorney or his family until the following afternoon when he was released. This release occurred after Tucson's Chief of Police learned that the fingerprints in issue did not belong to Cooper, that the people who had allegedly seen the Prime Time Rapist did not identify Cooper, and that the police department had no grounds to charge Cooper with any crime. ${ }^{110}$ Cooper's psychologist testified at the summary judgment hearing that Cooper was traumatized by the interrogation

full comparison between the latent prints attributed to the Prime Time Rapist and the known prints of Cooper. See id. at 1525. When questioned about the mistake, he replied, "I just screwed up." Id.

${ }^{101}$ See id. at 1524.

102 See id.

${ }^{103}$ See id.

${ }^{104}$ See id.

${ }^{105}$ See id.

${ }^{106} \mathrm{Id}$.

${ }^{107}$ See Cooper II, 963 F.2d 1220, 1230-31 (9th Cir.) (en banc), cert. denied, 113 S.

Ct. 407 (1992).

${ }^{108}$ See Cooper I, 924 F.2d at 1524.

${ }^{109}$ See id.

${ }^{110}$ See id. at 1525. 
and suffered from post-traumatic stress syndrome. ${ }^{111}$ The police never filed any charges against Cooper for the crimes of which he was accused. ${ }^{112}$

In Cooper's subsequent $\S 1983$ action against the two police departments, the district court denied the defendants qualified immunity. On appeal, the Ninth Circuit reversed, holding that the police department's failure to honor Cooper's request to remain silent and to speak with an attorney after they Mirandized him could not establish a Fifth Amendment violation. ${ }^{113}$ The Cooper I court stated that

[t]he Miranda warnings and rights are not themselves constitutionally mandated, but are rather procedural safeguards, or prophylactic measures, to ensure that the Fifth Amendment right against compulsory incrimination is not violated.... [Because] Miranda requirements are not a constitutional prerequisite, their violation cannot form the basis of a section 1983 suit. ${ }^{114}$

Furthermore, the court held that a Fifth Amendment violation, in contrast to a violation of the Fourth, Sixth, and Fourteenth Amendments, does not occur until a statement is introduced against a defendant in a criminal trial. ${ }^{115}$ Since no incriminating statement was taken from Cooper and no trial ensued, no Fifth Amendment violation occurred. ${ }^{116}$ The court unhappily recognized that its holding would give police the discretion to decide when to follow the dictates of Miranda and that the only remedy for violation would be the exclusion of evidence at trial. ${ }^{117}$ It concluded, however, that "if there is to be any harsher penalty imposed for a simple violation of Miranda rights, we will have to wait for word from Congress or the Supreme Court."118

It should be noted here that Cooper I, like the Warren case discussed above, ${ }^{119}$ involved an intentional refusal to honor Miranda, rather than a mere failure to warn. Moreover, the facts of Cooper I were more egregious than the Warren facts: the officers and their superiors in Cooper I planned to ignore all suspects'

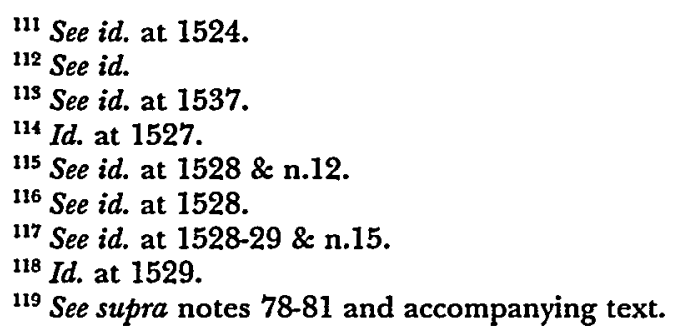


requests for counsel in advance of any arrests.

\section{c. Immunities, Color of Law, Proximate Cause, and Issue Preclusion}

Given that the Fifth Amendment is not violated until an involuntary statement is used against a suspect in a judicial or quasijudicial proceeding, a third major impediment to a $\S 1983$ suit arises. This obstacle implicates the interplay between the Fifth Amendment timing issue and the immunities for the various state actors involved. The confluence of these factors effectively undermines all $\S 1983$ actions based upon a Fifth Amendment violation. In these cases, either the court properly excludes such statements, or judicial and prosecutorial immunity protect those governmental officials, while the legal doctrines of color of law, collateral estoppel, and proximate cause protect the police officers.

It is well established that judges and prosecutors enjoy absolute immunity from all civil suits arising out of actions that occur in a courtroom. ${ }^{120}$ This immunity protects them from any civil rights action stemming from a violation of the Self-Incrimination Clause because such an injury can occur only during a trial. Whether the prosecutor knew or believed the confession was the product of state compulsion is irrelevant. ${ }^{121}$

Likewise, an aggrieved suspect cannot successfully sue the interrogating police officer who subsequently participates in the introduction or attempted introduction of the coerced statement. The first obstacle is that an officer's testimony is not given "under color of law," a requirement for a $\S 1983$ action. For example, in Edwards v. Vasel, ${ }^{122}$ plaintiff James Dale Edwards sued a St. Louis County police officer under the Civil Rights Act. Edwards alleged that the officer testified perjuriously in Edwards's habeas corpus

${ }^{120}$ See Buckley v. Fitzsimmons, 113 S. Ct. 2606, 2613 (1993) (holding that acts undertaken by a prosecutor in preparing for the initiation of judicial proceedings or for trial, and which occur in the course of her role as advocate for the State, are entitled to the protections of absolute immunity); $c f$. Forrester v. White, 484 U.S.219, 228 (1988) (holding that although judges enjoy absolute immunity for judicial or adjudicatory acts, a state court judge did not have absolute immunity from a damage suit under $\S 1983$ for his administrative decision to demote and dismiss a probation officer on account of her gender).

${ }^{121}$ If the prosecutor actually participated in the interrogation, she would receive only qualified immunity from suit based upon that act. Qualified immunity, however, would be sufficient to protect her. See infra notes 126-33 and accompanying text.

122349 F. Supp. 164 (E.D. Mo.), affd, 469 F.2d 338 (8th Cir. 1972). 
proceeding regarding whether a confession used against the plaintiff at his trial for murder was voluntary and that as a result of this perjury he was unsuccessful in obtaining relief. ${ }^{123}$ The court held that Edwards had no basis to sue because even if the officer falsely testified concerning what he had done, heard, and observed while clothed with his official authority, the testimony was given after the performance of his official duties and was thus not given "under color of law."124 The defendant police officer "testified as a witness [and i]n this respect was no different than any other witness." 125

Deeper consideration of this issue reveals the fallacy of the Edwards's court's reasoning. Its holding is plainly wrong. Since the purpose behind custodial interrogation is to secure a confession, and the officer is the only one present besides the defendant, it is fully expected that the officer will eventually have to testify in court. During my tenure with the District of Columbia United States Attorney's Office, I was required to complete specific forms given to Assistant United States Attorneys by the D.C. Police Department for the purpose of calling officers into trials and suppression hearings. These officers were paid overtime for such appearances and disciplined if they failed to appear. Under the court's reasoning, however, the officer is not liable under the Fifth Amendment for coercing a confession prior to its use in court, and, at the same time, he is insulated from liability once the confession reaches court because, by then, he is testifying as a mere witness and is not a state actor.

A second method by which police officers escape civil rights liability, regardless of whether they take the witness stand or whether the judge rules correctly, involves the application of the doctrine of collateral estoppel. State court judgments receive res judicata effect in subsequent federal $\S 1983$ actions. ${ }^{126}$ Moreover,

123 See id. at 165 .

${ }^{124} \mathrm{Id}$.

${ }^{125}$ Id. at 166. This reasoning would apply where the officer gave false testimony at the original trial as well as in a habeas proceeding. See, e.g., Briscoe v. LaHue, 460 U.S. 325, 335-36 (1983) (holding that $\$ 1983$ does not authorize a damages claim against private witnesses), cert. denied, 460 U.S. 1037 (1983); Bennett v. Passic, 545 F.2d 1260, 1263-64 (10th Cir. 1976) (holding that police officers testifying as witnesses at trial are not acting under color of state law); Williams v. Tansey, $610 \mathrm{~F}$. Supp. 1083, 1085 (E.D. Pa. 1985) (holding that $\S 1983$ does not create a damages remedy against police officers for their testimony as witnesses).

${ }^{126}$ See 28 U.S.C. § 1738 (1988) (affording state court judgments the same full faith and credit in every federal court as they have in states from which they are taken); 
the federal common law rule of preclusion is appropriately applied to $\S 1983$ actions. ${ }^{127}$ These doctrines act to bar a civil suit based upon an involuntary confession once the confession has been ruled voluntary by the criminal court.

In Hickombottom v. McGuire, ${ }^{128}$ an inmate convicted of armed robbery and felony murder sued officers of the Chicago Police Department who arrested him, alleging that they violated his Fourteenth Amendment right to due process by denying him food and water for an unreasonable length of time and violated his Fifth and Fourteenth Amendment rights not to incriminate himself by coercing his confession. ${ }^{129}$ The court granted the police officers' summary judgment motion, holding that principles of issue preclusion barred the plaintiff from pursuing his claim because the state trial court had already explicitly found the confession at issue to be voluntary. ${ }^{130}$

Finally, the application of the doctrine of proximate causation also prevents liability from being placed upon officers. In Gonzalez v. Tilmer, ${ }^{131}$ an inmate who had been convicted of aggravated battery, armed violence, and attempted murder brought a $\$ 1983$ action against a police officer for allegedly coercing his confes-

Migra v. Warren City Sch. Dist. Bd. of Educ., 465 U.S. 75, 85 (1984) (applying the doctrine of claim preclusion to state court judgments); Allen v. McCurry, 449 U.S. 90, 95-96 (1980) (applying the doctrine of issue preclusion to state court judgments).

127 See University of Tennessee v. Elliott, 478 U.S. 788, 797-99 (1986) (extending common-law principles of issue preclusion such that when a state administrative body acting in a judicial capacity resolves a disputed factual issue properly before it that the parties had an adequate opportunity to litigate, "federal courts must give the agency's factfinding the same preclusive effect to which it would be entitled in the State's courts").

${ }^{228} 765$ F. Supp. 950 (N.D. Ill. 1991).

${ }^{129}$ See id. at 953.

${ }^{130}$ See id. at 954 (citing Allen, 449 U.S. at 94-105). The converse of the court's holding regarding collateral estoppel, however, may not hold true. If a confession were held involuntary in a pretrial suppression hearing, at trial, or on appeal, this determination would probably not act as issue preclusion in favor of the plaintiff and against the officers and attorney defendants in a subsequent $\$ 1983$ action. At the time of this court determination, the prosecutor may have no motive to appeal the adverse ruling because she could not have anticipated a subsequent $\S 1983$ action based upon it. She may feel that the case against the defendant is strong enough to go forward without the statements, or that her office may not have the resources to pursue all such appeals. Furthermore, it may be that police officers are not considered parties to the suppression motion, and thus there could be no issue preclusion against them. The resolution of this issue would be a matter of individual state law under Migra, see supra note 126 , and some states have stricter rules regarding mutuality and identity of interests than others.

131775 F. Supp. 256 (N.D. Ill. 1991). 
sion. ${ }^{132}$ The court held that the officer could not be held liable for the introduction of allegedly coerced statements at trial because a policeman who takes a statement is not responsible for determining whether the statement was sufficiently voluntary to be admitted. ${ }^{133}$

The Supreme Court, last term, constructed additional barriers to such suits. In Heck $v$. Humphrey, ${ }^{134}$ the plaintiff alleged in a $\S 1983$ damage suit that his conviction for manslaughter was a result of malicious prosecution by the county prosecutors and a state police investigator. Declining to rule on the unraised issue of whether the suit was barred by res judicata, ${ }^{135}$ the Court dismissed his action. The Court held that "in order to recover damages for allegedly unconstitutional conviction or imprisonment or for other harm caused by actions whose unlawfulness would render a conviction or sentence invalid," a $\S 1983$ plaintiff must prove that his conviction was reversed by a state court on appeal or a federal court on habeas or expunged by executive order. ${ }^{136}$ Thus, to obtain damages for time spent in prison after a criminal conviction based upon a coerced confession, a $\S 1983$ plaintiff (assuming she could somehow overcome the various immunities, color of law, and proximate causation bars) must successfully have her conviction reversed. Since the recent application of the harmless error doctrine to coerced confession cases, however, it is no longer true that an unlawful confession necessarily renders a conviction invalid. Thus, the Heck reasoning would theoretically permit a $\$ 1983$ plaintiff whose criminal conviction was not overturned solely because of a harmless error ruling to bring an action for violation of the Self-Incrimination Clause if an involuntary confession were admitted in her trial. Her damages, however, would be limited to

132 See id. at 258. This plaintiff had exhausted his habeas corpus remedies. The court found that he had waived his claim regarding his allegedly coerced statements by failing to raise it on direct appeal. See id. at 259-60.

${ }^{133}$ See id. at 260 . The court further noted that the plaintiff had procedures available to protect his right to a fair trial, independent of any role the police played in obtaining his statement, by simply making a motion to have the statement suppressed. See id.; see also Duncan v. Nelson, 466 F.2d 939, 942 (7th Cir.) (holding that police officers who coerced defendant's confession were not the proximate cause of the confession's introduction at trial because it was untenable that the officers would foresee that the trial judge would erroneously admit the unlawful confession), cert. denied, 409 U.S. 894 (1972).

${ }^{134} 114$ S. Ct. 2364 (1994).

135 See id. at 2369 n.2.

${ }^{136} \mathrm{Id}$. at 2372. 
any "actual, compensable injury, [which] . . . does not encompass the 'injury' of being convicted and imprisoned." 137 This results in no damage award at all. The Fifth Amendment violation does not occur until trial, so there are no damages arising from the interrogation itself. Once at the trial stage, there are still no damages because the harmless error ruling means that the plaintiff would have been convicted despite the admission of the confession. Overall, Heck has the effect of barring suits by the guilty, those sabotaged by ineffective counsel or by the procedural maze on habeas, and those who discover a constitutional wrong or exculpatory evidence only after release from custody.

The combination of legal doctrines discussed above appears to unfairly deny all remedies. If the plaintiff should lose on the issue of voluntariness at trial or in a pretrial proceeding, she will have no $\S 1983$ claim because of collateral estoppel and because the officer was not the proximate cause of the adverse ruling and resulting injury to the plaintiff. This appears fair, for if there were no Miranda violation there should be no remedy. On the other hand, if a statement taken in violation of Miranda is erroneously admitted by the criminal trial judge, and if an appellate court subsequently reverses on the grounds that Miranda and/or the Self-Incrimination Clause itself was violated, the suspect would still have no $\$ 1983$ action. She cannot sue the prosecutor or judge because of absolute and qualified immunity, and she cannot sue the officers involved because they were not acting "under color of law" and were not the proximate cause of the plaintiff's original conviction. This reasoning denies a remedy despite the existence of an actual Fifth Amendment violation.

Likewise, if the $\S 1983$ plaintiff should win on the issue of the voluntariness of her confession in her criminal trial, the judge who finds her statement to be involuntary or in violation of Miranda will exclude the statement. The plaintiff will again have no $\$ 1983$ action because the Fifth Amendment violation will have been avoided. The same result occurs when a plaintiff is unlawfully interrogated but makes no statement. This unfairly denies a remedy to both the innocent and the guilty suspect for the harm occasioned by the unlawful interrogation itself.

${ }^{237}$ Id. at 2372 n.7 (citation omitted). 


\section{Cases Permitting a $\S 1983$ Action}

Although only one court has held that the failure of police to honor a suspect's invocation of his Miranda rights amounts to a Fifth Amendment violation, ${ }^{138}$ several courts have held that where a suspect was actually coerced by egregious police conduct into confessing, ${ }^{139}$ a $\S 1983$ action premised upon the violation of substantive due process was appropriate. ${ }^{140}$

The initial such case was Duncan v. Nelson. ${ }^{141}$ Plaintiff James Richard Duncan sued six Chicago police officers for damages based upon the alleged involuntary confession extracted by them. ${ }^{142}$

${ }^{138}$ See infra note 161 and accompanying text (discussing the Cooper II decisions). In Dimmick v. State, 473 P.2d 616, 619 (Alaska 1970), the prosecutor introduced the testimony of Lee Herman, who had admitted committing a robbery with the defendant, and the defendant was convicted. The Alaska Supreme Court held that Herman's confession was made after the police intentionally ignored his request for an attorney. See id. The Court upheld Dimmick's conviction, concluding in dicta that the appropriate remedy for the constitutional wrong suffered by Herman would be a civil rights action by him against the police officers. See id. at 619-20. However, I can find no record of such a suit ever being initiated.

${ }^{199}$ The critical distinction here is between actual police coercion and the presumption of coercion afforded a confession taken in violation of the Miranda warnings.

${ }^{140}$ There are three pre-Miranda cases allowing a $\$ 1983$ claim based upon physically coerced confessions. See Robichaud v. Ronan, 351 F.2d 533, 534-37 (9th Cir. 1965) (allowing $\S 1983$ claim by a juvenile plaintiff based on her allegation that the defendants unsuccessfully attempted to intimidate her into confessing to crimes that she did not commit, with the intent to deprive her of her right to counsel, and of inflicting mental and physical damage, in violation of Sixth and Fourteenth Amendments); Geach v. Moynahan, 207 F.2d 714, 715, 717 (7th Cir. 1953) (allowing $§ 1983$ claim where police illegally seized and searched plaintiff, subjected him to hours of brutal interrogation in an attempt to coerce a confession, refused him the right to contact counsel, refused to charge him with a crime or take him before a judge, and held him for six days); Refoule v. Ellis, 74 F. Supp. 336, 339 (N.D. Ga. 1947) (allowing claim for violation of due process based on allegations of the successful coercion of a confession by prolonged relays of questioning and infliction of violence, in conjunction with confinement of plaintiff by police without either a warrant or probable cause to arrest).

Additionally, in a prosecution brought under 18 U.S.C. $\$ 242$, a criminal statute with requirements similar to $\$ 1983$, the Court held that the Fourteenth Amendment right not to be subject to punishment without due process of law was violated when a Florida special police officer used brutal methods to beat confessions from the suspects. See Williams v. United States, 341 U.S. 97, 101-03 (1951).

${ }^{141} 466$ F.2d 939 (7th Cir.), cert. denied, 409 U.S. 894 (1972).

${ }^{142}$ Two of the defendants took Duncan into custody as he was leaving Boys Court. He was thereafter removed to an upstairs room, handcuffed to a chair, and jointly and individually interrogated by all of the defendants for over 12 hours concerning the murder of Samuel Schwartz. As a result of this interrogation, Duncan orally confessed, and he signed a written confession six hours later. See id. at 940-41. This confession was admitted at trial over Duncan's objection and in January of 1960 
Accepting as true the facts found in the Illinois Supreme Court opinion, the district court dismissed the complaint on the ground that, inter alia, the defendant police officers could not be held liable for the improper acts of an Illinois state court in admitting an involuntary confession into evidence. ${ }^{143}$ The Seventh Circuit reversed the order of dismissal and remanded for trial. ${ }^{144} \mathrm{It}$ agreed with the district court that the improper act of the trial court in admitting the involuntary confession was not attributable to the police officers. Thus, the police officers were not the proximate cause of the plaintiff's imprisonment and were not liable for any damages arising from his conviction. ${ }^{145}$ The appellate court construed the complaint more broadly, however, as seeking damages not only for the nine years of illegal imprisonment and resulting lost wages but for the alleged pain, injury, and mental anguish of the interrogation itself. ${ }^{146}$

The Duncan court conceded that a mere violation of the precepts of Miranda did not transform the interrogation into an actionable tort. ${ }^{147}$ The court found, however, that "the Fourteenth Amendment prohibited compulsion to incriminate oneself by fear of hurt, torture, exhaustion, or any other type of coercion that falls outside the scope of due process." ${ }^{148}$ Furthermore, physical violence is not a prerequisite to a $\S 1983$ action based on the

he was found guilty and sentenced to 30 years imprisonment. See id. In December of 1968, the Illinois Supreme Court held that the confession was involuntary and reversed the conviction. See id. That court found as uncontroverted fact that Plaintiff Duncan had been in custody on an unrelated charge immediately prior to his interrogation by the defendants. See id. at 941 . Furthermore, for 18 days prior to the interrogation at issue, Duncan had been placed in the "hole,' a form of solitary confinement, where he slept on the floor, received one meal a day, and saw neither family nor friends." Id. The court found that the defendant police officers knew, on the morning of Duncan's arrest, that he had been in the "hole." See id. Duncan was acquitted at his new trial. Id. at 940-41.

${ }^{143}$ See id. at 940.

144 See id. at 945 .

${ }^{145}$ See id. at 942 . Of course, the judge cannot be liable because of her absolute judicial immunity. See supra note 120; see also Stump v. Sparkman, 435 U.S. 349 (1978).

${ }^{146}$ See Duncan, $466 \mathrm{~F} .2 \mathrm{~d}$ at 943.

${ }^{147}$ See id. at 944 .

${ }^{148}$ Id. The Illinois Supreme Court set aside plaintiff's earlier conviction, finding it unnecessary to reach his allegations of physical violence and threats. See People v. Duncan, 238 N.E.2d 595 (Ill. 1968); see also Duncan, 466 F.2d at 941 . Since there had been no finding on this issue, the federal appellate court held that the plaintiff was not precluded from presenting his proof on the issue of physical violence in his civil rights action. See id. at 945 . 
extraction of an involuntary confession. ${ }^{149}$

Two later cases followed suit. In Rex $v$. Teeples, ${ }^{150}$ the Tenth Circuit denied summary judgment to a district attorney and a police officer based upon a citizen's allegation that he was denied liberty by being placed under a seventy-two-hour mental hold and that he was psychologically coerced into giving an involuntary confession. ${ }^{151}$ The court found that both of these claims were actionable as possible violations of substantive due process. ${ }^{152}$

Likewise, in Buckley $v$. Fitzsimmons, ${ }^{153}$ the plaintiff filed suit under $\S 1983$ against the police officers and prosecutors involved in his criminal case, alleging that they conspired to execute him even though they knew he was innocent. ${ }^{154}$ In a lengthy discussion of

${ }^{149}$ Duncan, 466 F.2d at 945 (Harlan, J., concurring) (citing Spano v. New York, 360 U.S. 315 (1959) and Monroe v. Pape, 365 U.S. 167, 196 n.5 (1961)). Further support can be found in Chrisco v. Shafran, 507 F. Supp. 1312, 1318 (D. Del. 1981). Citing Duncan, the Chrisco court acknowledged that there is "some authority for the proposition that there is a cause of action for damages for an involuntary confession obtained by 'fear of hurt, torture, exhaustion . . ' or other coercion because such police conduct offends the requirements of decency and fairness "implicit in the concept of ordered liberty' imposed upon the states by the due process clause." Id. The court dismissed the plaintiff's action because no facts supported the conclusion that the defendants engaged in unlawful coercion intended to produce an involuntary confession. See id.

${ }^{150} 753$ F.2d 840 (10th Cir.), cert, denied, 474 U.S. 967 (1985).

151 Plaintiff Rex had been admitted to the hospital after attempting suicide by carbon monoxide poisoning. See id. at 841 . While there, Officer Teeples represented himself to Rex as a minister as well as a police officer and questioned him regarding a recent kidnapping. See id. Rex alleged that Teeples convinced the attending physician to place Rex under a 72-hour mental hold because Teeples had not yet developed probable cause to arrest. See id. at 841-42. Rex also alleged that both Teeples and Johnson, Chief Deputy District Attorney, took turns interrogating him for four to five hours. See $i d$. at 842 . The Colorado appellate court, in reversing Rex's kidnapping conviction, agreed that "the police took advantage of his confused mental state ... [and] deceived him into believing [that] he was not a suspect" in a crime. Id. (citing People v. Rex, 636 P.2d 1282 (Colo. Ct. App. 1981)).

152 See id. at 842-43.

153919 F.2d 1230 (7th Cir. 1990), vacated and remanded, 112 S. Ct. 40 (1991), affd as modified, 952 F.2d 965 ('7th Cir. 1992), rev'd on other grounds, 113 S. Ct. 2606 (1993).

154 See id. at 1235-36. In Buckley, a highly publicized and unsolved brutal rape and murder of a young girl coincided with the reelection campaign of the local prosecutor. Unable to convince the first three experts, who were regularly employed by the state, that a boot print found at the home of the victim belonged to Buckley, prosecutors contacted a fourth expert witness, one with a reputation for fabricating results, who agreed that the boot print matched a boot belonging to Buckley. Buckley was tried twice for this crime. The first trial, at which this fourth expert testified for the prosecution, resulted in a hung jury. Shortly after this trial, another man confessed to the murder at issue. Prosecutors apparently disbelieved that confession and were preparing for a second trial against Buckley when their expert witness suddenly died. Charges were subsequently dismissed, and Buckley was 
the doctrine of immunity, Judge Frank $H$. Easterbrook held that the prosecutor would be entitled to absolute immunity for the act of conducting an interrogation of defendant without giving him Miranda warnings because no Fifth Amendment violation occurs unless and until the statements are used in a criminal proceeding. ${ }^{155}$ If, however, the prosecutor coerced a confession by "depriving a suspect of food and sleep during an interrogation, or beating him with a rubber truncheon," then the constitutional injury is complete, and causes injury out of court. ${ }^{156}$ In that case, only qualified immunity would be available. The court finally held that the dismissal for Fitzsimmons was premature because it could not be gleaned from the record whether Buckley was relying on Miranda or due process. ${ }^{157}$

The Ninth Circuit, in its en banc ruling in Cooper II, took both the Fifth Amendment and due process analyses where no court had ever gone before. As noted above, the Cooper I court held that the Fifth Amendment was not violated and thus no $\S 1983$ action was sustainable on the facts of that case. ${ }^{158}$ Additionally, that court held that the conduct of the police in ignoring Miranda and in using psychological pressure during a four-hour interrogation (in an attempt to secure a confession from Cooper) was not conduct that sufficiently shocked the conscience of the court so as to constitute a substantive due process violation. ${ }^{159}$ "This conduct was simply

released after spending three years in prison, unable to raise his $\$ 2$ million bond. See id. at 1234-35.

${ }^{135}$ See id. at 1244 . The court went further than merely noting that conducting an interrogation in the absence of Miranda warnings was not a violation of a suspect's rights. The court stated that actually "compelling" a suspect to speak, where the compulsion does not involve practices forbidden by other constitutional prerequisites, is likewise not a constitutional violation so long as the results are not used against the suspect in court. See id. The Fifth Amendment right not to incriminate oneself is an evidentiary privilege and thus cannot be violated outside the courtroom. See id.

${ }^{156} \mathrm{Id}$.

${ }^{157}$ The Supreme Court did not address this issue in Buckley because it was not before them. The Court simply noted the Seventh Circuit's reasoning in a footnote:

The [lower] court reasoned that, because claims based upon Miranda $v$. Arizona ... and the Self-Incrimination Clause of the Fifth Amendment depend on what happens at trial, prosecutors are entitled to absolute immunity for those claims; by contrast, only qualified immunity is available against petitioner's claims as to "coercive tactics that are independently wrongful."

Buckley, 113 S. Ct. at $2611 \mathrm{n} .2$ (citation omitted).

${ }^{158}$ See supra notes 93-118 and accompanying text (discussing the facts and holding of Cooper I).

${ }^{139}$ See Cooper I, 924 F.2d 1520, 1530 \& n.20 (9th Cir. 1991), rev'd en banc, 963 F.2d 
not as serious as in cases in which substantive due process violations have been found, as, for example, in the instances of serious police brutality or deliberate indifference toward a citizen who the police have placed in danger or to whom they owe a duty. ${ }^{160}$

The Ninth Circuit en banc panel, in a seven-one-three decision, reversed the original panel's decision. In Cooper $I{ }^{161}$ the full court held that the Fifth Amendment was violated by the police officials coercing Cooper, after he invoked his right to remain silent, into making potentially incriminating statements, which were never introduced against him at trial. ${ }^{162}$ This holding that the Fifth Amendment's Self-Incrimination Clause applied to a suspect's statements made "in the sheriff's department," 163 and which "the prosecution might have used at trial,"164 defies precedent ${ }^{165}$ and is not likely to be followed by any other circuit. ${ }^{166}$ The majority had no case support for its position. Although it quoted long passages from the Miranda decision that appeared to support its position, these passages have been repudiated. ${ }^{167}$ The preincorporation cases cited ${ }^{168}$ to support the claimed violation of the privilege against self-incrimination discuss only the Due Process Clause of the Fourteenth Amendment and thus, in those cases, the Court had no need to decide whether or when a Fifth Amendment violation occurred.

Likewise, the post-incorporation cases cited by the majority, ${ }^{169}$

1220 (9th Cir.), cert. denied, 113 S. Ct. 407 (1992).

${ }^{160} \mathrm{Id}$. at 1530 .

${ }^{161} 963$ F.2d 1220 (9th Cir.) (en banc), cert. denied, 113 S. Ct. 407 (1992). David Berkman, attorney for the defendant, noted that the case was settled in October 1993, the day it was set for trial. Telephone Interview with David L. Berkman, Murphy, Goering, Roberts \& Berkman, P.C. (Nov. 11, 1993).

${ }^{162}$ See id. at 1241-42.

${ }^{163}$ Id. at 1242.

${ }^{164} I d$. at 1237.

${ }^{165}$ See supra part I.B.1.b (noting that the Fifth Amendment can only be violated in court).

${ }^{166}$ The Fourth Circuit, in dicta, has already rejected Cooper II. In Wiley v. Doory, 14 F.3d 993, 996 (4th Cir. 1994), the court held that statements compelled from a police officer by the threat of job loss did not violate the Self-Incrimination Clause absent either "a compelled waiver of the Fifth Amendment privilege or the use of the compelled statements against the maker in a criminal proceeding." Finding the Cooper II dissent "persuasive," the court dismissed the officer's $\$ 1983$ suit based upon qualified immunity. Id. at 998.

${ }^{167}$ See supra part I.A (discussing the deconstitutionalization of Miranda).

${ }^{163}$ The Cooper II court cited to Spano v. New York, 360 U.S. 315 (1959) and Haynes v. Washington, 373 U.S. 503 (1963). See Cooper II, 963 F.2d at 1243.

${ }^{169}$ Cooper II, 963 F.2d at 1241, 1245-47. The court cited Michigan v. Tucker, 417 
which did discuss the privilege, held only that there is a distinction between actual compulsion and presumed compulsion, not that the Fifth Amendment can be violated at the station house. Thus, by ignoring the requirement that a statement be used in a criminal trial and by defining Miranda violations as compulsion, the Cooper II court sanctioned a cause of action based upon the Fifth Amendment whenever Miranda is violated. ${ }^{170}$ Second, the Cooper II court held that substantive due process was violated both by the coercion of non-incriminating statements and by the Task Force's unlawful plot to deprive Cooper of the privilege of testifying in his own defense and presenting an insanity defense. ${ }^{171}$ These few exceptional cases will not serve to protect or enforce the dictates of Miranda. One of them, Cooper II, is simply incorrect, and the rest are actually police brutality and not confession cases. Thus, the problem outlined in the introduction of this Article remains unsolved.

\section{The Consequences of ABANDONING MIRANDA}

A suspect's "right" to receive her Miranda warnings and to have her invocation of the rights contained in those warnings honored has been affirmed in recent court decisions. "Beyond this duty to inform, Miranda requires that the police respect the accused's decision to exercise the rights outlined in the warnings. 'If the individual indicates in any manner, at any time prior to or during questioning, that he wishes to remain silent, ... the interrogation must cease.'"172 Likewise, in order to prevent police from badger-

U.S. 433, 441 (1974) ("Where the State's actions offended the ... Due Process Clause, the State was then deprived of the right to $u s e$ the resulting confessions in court.") (emphasis added) and Mincey v. Arizona, 437 U.S. 385, 402 (1978) (holding that a confession in a hospital bed was actually involuntary and, therefore, "[d]ue process of law requires that statements obtained as these were cannot be used in any way against a defendant at his trial") (emphasis added).

${ }^{170}$ Apart from the problem that Cooper's testimony was never used in a judicial proceeding, the Cooper II court did not require any actual coercion of the suspect in the due process sense. The court's assertion that there is no "cause of action where police officers continue to talk to a suspect after he asserts his rights and where they do so in a benign way, without coercion or tactics that compel him to speak," Cooper II, $963 \mathrm{~F} .2 \mathrm{~d}$ at 1244 , is nonsense. Prior to this statement, the court declares that custodial interrogation is by definition coercive and that it is a "nightmare" to have your request for silence ignored. Id. at 1243. Thus, "benign" questioning appears impossible.

17 See infra part II.A.

172 Moran v. Burbine, 475 U.S. 412, 420 (1986) (citation omitted); see also Michigan v. Mosley, 423 U.S. 96 (1975) (holding that although police cannot reinterrogate defendant regarding robbery offense after he asserted his right to silence, a different 
ing a defendant into waiving her previously asserted Miranda rights, the Court last term affirmed that a suspect who has unambiguously invoked her right to counsel cannot be questioned regarding any offense, unless an attorney is actually present. ${ }^{173}$ Such rules are necessary to protect the privilege against self-incrimination, otherwise " $[w]$ hen a suspect understands his (expressed) wishes to have been ignored . . . in contravention of the 'rights' just read to him by his interrogator, he may well see further objection as futile and confession (true or not) as the only way to end his interrogation." 174

I believe that few of us would care to live in a society in which police officers could interrogate citizens at will for indeterminate periods of time (in other words, revert back to pre-Miranda "thirddegree" police techniques). ${ }^{175}$ While it is one thing to be questioned by an attorney or judge in open court (and even be compelled to answer if offered Kastigar-type immunity ${ }^{176}$ ), it is quite another to be interrogated in secret by law enforcement officials. Confession may be "good for the soul" when given to a listener who has your best interests at heart (such as a parent); it is certainly not good for the body when given to those whose utmost desire is to have you incarcerated or executed. This situation creates great harm to the suspect, regardless of whether any statements are ever used against him in a criminal trial. The autonomy and dignity of

detective can question defendant about unrelated homicide after new warnings are given).

${ }^{173}$ See, e.g., Davis v. United States, 114 S. Ct. 2350 (1994) (holding that only where a suspect unambiguously requests an attorney must questioning cease, although the "better" police practice would be to ask questions that clarify whether the request was actually made); Minnick v. Mississippi, 498 U.S. 146, 153 (1990) (holding that once a suspect requests counsel, police cannot reinitiate interrogation without counsel present, whether or not the suspect consulted with counsel); Edwards v. Arizona, 451 U.S. 477, 484 (1981) (holding that "when an accused has invoked his [Miranda] right to have counsel present during custodial interrogation, a valid waiver of that right cannot be established by showing only that he responded to further police-initiated custodial interrogation").

${ }^{174}$ Davis, 114 S. Ct. at 2362 (Souter, J., concurring). Souter argued for a rule requiring officers to clarify an ambiguous request for counsel before further questioning. See id. at 2359. Justice Souter also referred to Cooper II, 963 F.2d 1220 (9th Cir.) (en banc), cert. denied, $113 \mathrm{~S}$. Ct. 407 (1992), as an example of police behavior necessitating such a rule.

${ }^{175}$ Given the American public's response to the interrogation and subsequent punishment of Michael Fay by Singaporean officials, I am less certain of this proposition than when I began writing this Article. The elimination of the privilege against self-incrimination would, of course, require a constitutional amendment.

${ }^{176}$ See supra note 86 and accompanying text. 
the individual sought to be protected by the Self-Incrimination Clause is certainly lost.

Although the Court purports to reaffirm the stability and importance of the rights guaranteed by the Miranda decision, it has consistently refused to provide an adequate remedy for the violation of these rights. Given the legal obstacles to protecting the SelfIncrimination Clause, an outright disregard for Miranda's safeguards is precisely what is beginning to occur throughout the country. Law enforcement officials are in the business of solving crimes, not protecting constitutional rights. Since the values enshrined in the Self-Incrimination Clause, in certain instances, may not further the truth-seeking function of an investigation and trial, and since these values certainly do not serve the adversarial goals of officers and prosecutors, officers will be tempted to ignore them. Today's Court, by severely limiting the remedies available for violations of the Self-Incrimination Clause and the Miranda warnings, not only permits officers to ignore both but actually encourages their violation. The following consequences flow from abandoning the remedies for a violation of the Fifth Amendment values protected by Miranda.

\section{A. The Contours of an Interrogation Will Be Determined by the Executive Rather Than the Judiciary: Some "Real Life" Horror Stories}

This approach is problematic because it fails to create incentives for law enforcement officers to comply with Miranda. The Cooper case provides an excellent example of the response of such officers to this lack of incentives. The most interesting aspect of $\mathrm{Mr}$. Cooper's nightmare, from a scholarly point of view, is that the Arizona police had determined, in advance, that when they arrested a Prime Time Rapist suspect, they would "continue to ask him questions despite his request for silence or for an attorney." 177 They had decided "that the violent nature of the series of incidents and public safety demanded that the police obtain more information than following Miranda would allow." 178 Law enforcement's understanding of how present Supreme Court doctrine protects their actions is exhibited by the statement made by Detective

${ }^{177}$ Cooper I, 924 F.2d 1520, 1523 (9th Cir. 1991), rev'd en banc, 963 F.2d 1220 (9th Cir.), cert. denied, 113 S. Ct. 407 (1992).

${ }^{178} \mathrm{Id}$. at $1523 \mathrm{n} .1$. 
Weaver Barkman at the summary judgment hearing in the Cooper case. He testified:

I continued the interrogation, hoping that it would be at least held voluntary to keep him off the stand and to deprive him of the opportunity of forming an insanity defense .... [S]o those were my motives for violating, trampling on his civil rights and Mirandas [sic], and the bottom line being, what are his damages. I mean, I'm going to violate this American citizen's rights, but look at the totality of the circumstances, the big picture, is it worth it, yeah. ${ }^{179}$

I predict numerous similar incidents will follow in Cooper ITs wake. For example, a much publicized case in the Washington, D.C.-Baltimore area involved the disappearance of Laura Houghteling, a young Harvard graduate, from her mother's Bethesda, Maryland home in 1992. Although the police conducted extensive searches in three states and presumed the missing woman dead, her body has not yet been recovered. Hadden I. Clark, a homeless man who did odd jobs for Laura's mother, was arrested as a murder suspect. ${ }^{180}$ A county police department detective testified during a suppression hearing that the police department had intentionally decided not to advise Clark of his Miranda rights and to ignore his requests for an attorney during a seven-hour interrogation. ${ }^{181}$ The detective also stated that "homicide investigators 'put aside our normal standard procedures for the greater good' of possibly finding the bodies of Houghteling and other missing persons." 182 Apparently, these officers determined that this greater good necessitated ignoring Clark's "more than 100"

${ }^{179}$ Cooper II, 963 F.2d 1220, 1227 (9th Cir.) (en banc), cert. denied, 113 S. Ct. 407 (1992); see also People v. Winsett, 606 N.E.2d 1186 (Ill. 1992), cert. denied, 114 S. Ct. 102 (1993). In Winsett, police administered the Miranda warnings, ignored the defendant's unequivocal request for counsel, and obtained statements in which the defendant incriminated himself and identified his accomplice in a murder-for-hire scheme. See id. at 1190. While defendant's self-incriminating statements were suppressed at trial as violative of Miranda, the fruits of the violation-in the form of trial testimony by the accomplice-were admitted in the prosecutor's case-in-chief. See $i d$. at 1195. By allowing the evidence to be used in the prosecutor's case-in-chief, the Winsett Court provides no incentive for law enforcement officials to honor a Miranda request.

${ }^{180}$ See Veronica T. Jennings, Questioning of Suspect Defended: Police Wanted Clark to Help Find Bodies, WASH. POST, June 9, 1993, at B1. Clark was also a suspect in the 1986 disappearance of six-year-old Michele Dorr, who likewise vanished from her home and is presumed dead, although no body has been recovered. See id.

${ }^{181}$ See id.

${ }^{182} I d$. 
requests for an attorney during the interrogation and threatening Clark with "death in the gas chamber." 183 Although the prosecutors in the case conceded that police violated Clark's legal rights and would be barred from using Clark's statements at trial, police officials stated that "the violations of Clark's legal rights did not jeopardize their case against Clark because they already had enough evidence against him" without these statements. ${ }^{184}$

As these examples indicate, if we eliminate Miranda entirely, or simply retain its present status as a nonconstitutional prophylactic rule with no effective remedy available for its violation, then police officers can continue to ignore a suspect's request not to be interrogated. ${ }^{185}$ In fact, the incentive works in favor of ignoring such a request. There is still an advantage in giving the warnings; if a suspect agrees to waive his rights and gives a confession, that statement might be admissible in the prosecutor's case-in-chief. Once a suspect invokes his rights, however, his subsequent statements become inadmissible anyway, and police officers have nothing to lose by continuing the interrogation and something to gain, such as developing impeachment evidence and other leads. Of course, if the officers break off the interrogation and allow the suspect access to an attorney, the possibility of obtaining a confession are lost.

Thus, there is extreme dissonance between the content of the warnings and the actions of the officers. It is, at best, unseemly for the officers to offer rights which they proceed to ignore. A more honest approach would be to formulate new warnings in light of the limitations on Miranda. For example, the officer might say, "You do not have the right to remain silent. If you request silence or an

${ }^{183}$ Id. at $\mathrm{B} 2$ (recounting statements made by Clark's defense attorney).

${ }^{184} I d$. Clark pleaded guilty to the murder on June 14,1993 and was sentenced on June 25, 1993 to 30 years imprisonment. See Veronica T. Jennings \& Elisha King, Clark Gets 30 Years for Houghteling Murder, WASH. POST, June 26, 1993, at DI (describing Clark's sentencing).

${ }^{185}$ But these same officers still run the slight risk that a court, pursuant to Cooper $I I$, may declare that the statement was actually involuntary, that the taking of it was shocking in a substantive due process sense, and that therefore a $\S 1983$ action lies. As noted in Cooper II:

$[W]$ conclude that the facts and circumstances presented by Cooper state a cause of action under $\$ 1983$ for a violation of his right not to be subjected during custodial interrogation to police conduct that denies him the exercise of his "free and unconstrained will," a right to which he was entitled by the Due Process Clause of the Constitution.

963 F.2d 1220, 1248 (9th Cir.) (en banc), cert. denied, 113 S. Ct. 407 (1992). 
attorney, the interrogation will continue, but your statements cannot be used against you in the prosecutor's case-in-chief." This statement, however, is not what the Court mandated in Miranda.

An analogy to the Fourth Amendment's exclusionary rule would be profitable. Until 1961, the Supreme Court exhibited the same reluctance to enforce the Fourth Amendment's prohibition against unreasonable search and seizure as the Court presently displays toward enforcement of Miranda rights. Prior to and during the period when the Court held that the federal exclusionary rule ${ }^{186}$ did not apply to the states, ${ }^{187}$ until twelve years later when the Court reversed itself and held that states were bound by the exclusionary rule, ${ }^{188}$ many law enforcement officials in larger jurisdictions such as California and New York disregarded with impunity citizens' Fourth Amendment right to be free from unreasonable searches and seizures. ${ }^{189}$ Of course, the substance

${ }^{186}$ See Weeks v. United States, 232 U.S. 383, 398 (1914) (holding that evidence taken in violation of the Fourth Amendment is excluded from federal criminal trials), overruled by Mapp v. Ohio, 367 U.S. 643 (1961).

${ }^{187}$ See Wolf v. Colorado, 338 U.S. 25, 38 (1949) (stating that 31 states then admitted illegally seized evidence), overruled by Mapp v. Ohio, 367 U.S. 643 (1961).

${ }^{188}$ See Mapp v. Ohio, 367 U.S. 643, 653 (1961) ("It, therefore, plainly appears that the factual considerations supporting the failure of the Wolf court to include the Weeks exclusionary rule when it recognized the enforceability of the right to privacy against the States in 1949 . . could not, in any analysis, now be deemed controlling.").

${ }_{189}$ See, e.g., Edward L. Barrett, Jr., Exchusion of Evidence Obtained by Illegal SearchesA Comment on People v. Cahan, 43 CAL. L. Rev. 565 (1955). Barrett noted:

[P]rior to the [adoption of a state exclusionary rule in California] the police were under no substantial pressure to seek clarification of [the Fourth Amendment]. The issue of legality became crucial so seldom that the police had, in effect, broad discretion in determining the procedures to follow, subject only to community pressures, particularly those by the press, which rarely focused upon any but the most obvious abuses.

Id. at 577. Other commentators have discussed the problem. For example, Judge Roger J. Traynor, discussing his opinion in People v. Cahan, 282 P.2d 905 (Cal. 1955), in which the California Supreme Court adopted the federal exclusionary rule as a matter of state law, noted:

It became impossible to ignore the corollary that illegal searches and seizures were also a routine procedure subject to no effective deterrent; else how could illegally obtained evidence come into court with such regularity? It was one thing to condone an occasional constable's blunder, to accept his illegally obtained evidence so that the guilty would not go free. It was quite another to condone a steady course of illegal police procedures that deliberately and flagrantly violated the Constitution of the United States ....

Roger J. Traynor, Mapp v. Ohio at Large in the Fiffly States, 1962 DukE L.J. 319, 322; see also Sidney E. Zion, Detectives Get a Course in Law: They Return to Classroom to Study 
of the Fourth Amendment remains unchanged regardless of the remedy for its violation. Thus law enforcement officials should have been learning and obeying search and seizure rules as dictated by the Court regardless of the existence of an exclusionary rule. This, however, did not occur. ${ }^{190}$ Because the Court did not enforce these Fourth Amendment rights by providing a remedy for their violation, many prosecutors' offices and police precincts were unconcerned with upholding them and could not be troubled to train their law enforcement personnel as to the content of this amendment. ${ }^{191}$

This natural human tendency to assume that where there is no remedy, there must be no right, ${ }^{192}$ is repeated in Fifth Amendment jurisprudence. ${ }^{193}$ If no remedy is provided for a Miranda

Court Decisions, N.Y. TIMES, Apr. 28, 1965, at 50 ("'Before [Mapp] nobody bothered to take out search warrants. Although the Constitution requires warrants in most cases, the Supreme Court had ruled that evidence obtained without a warrantillegally if you will-was admissible in state courts. So the feeling was, why bother?') (remarks of Leonard Reisman, then New York City Deputy Police Commissioner in charge of legal matters).

${ }^{190}$ For an excellent discussion of this point, see Kamisar, supra note 28, at 551-69.

${ }^{191}$ See, e.g., H. Richard Uviller, The Acquisition of Evidence for Criminal Prosecution: Some Constitutional Premises and Practices in Transition, 35 VAND. L. REV. 501 (1982). Professor Richard Uviller, a state prosecuting attorney at the time Mapp was handed down, stated:

I cranked out a crude summary of federal search and seizure and suppression law just before the State District Attorney's Association convened . . . . I had an instant runaway best seller. It was as though we had made a belated discovery that the fourth amendment applied in the State of New York ....

Id. at 502; see also Walter Mondale, The Problem of Search and Seizure, BENCH \& B. MINN., Feb. 1962, at 15. Mondale states:

The very fact that these [post-Mapp] institutes are being held is eloquent testimony ... of the basic wisdom of the Court's decision. We are doing today, because of the Court's ruling, what we should have done all along. We are studying ways in which we can bring our police methods and procedures into harmony with the constitutional rights of the people we serve.

Id. at 17.

192 See Milton A. Loewenthal, Evaluating the Exclusionary Rule in Search and Seizure, 49 UMKC L. REV. 24 (1980). Loewenthal, an Associate Professor of Law and Criminal Justice at John Jay College of Criminal Justice of the City University of New York, reported the findings of a study of New York police perceptions about the Fourth Amendment exclusionary rule. See id. at 29. The study found that "police officers could neither understand nor respect a Court which purported to impose constitutional standards on the police without excluding evidence obtained in violation of those standards." Id.

${ }^{193}$ One could argue that these Fourth and Fifth Amendment situations are not analogous because presently statements taken in violation of Miranda are excluded 
violation, officers will simply stop offering and honoring these warnings. If there is no remedy for a Fifth Amendment violation, officers will discover this as well and ignore the Fifth Amendment. Thus, in regard to the Self-Incrimination Clause, we are in danger of the same kind of lawlessness that we experienced toward Fourth Amendment rights prior to $M a p p .^{194}$

\section{B. Inappropriateness of a Right Without Remedy}

If there exists, as the United States Supreme Court claims, a right to be free from interrogation in the absence of Miranda warnings and/or a right to have one's invocation of the right to remain silent or to consult with an attorney respected, ${ }^{195}$ then at present this is a right without a remedy. ${ }^{196}$ Allowing a civil rights remedy of either damages or injunctive relief would protect both innocent and guilty victims from brutal police practices. ${ }^{197}$

from a prosecutor's case-in-chief, while in pre-Mapp days, evidence taken in violation of the Fourth Amendment was not excluded. Nevertheless, the basis for the analogy survives. In the Fifth Amendment context, police officers benefit from ancillary use of the excluded statements and can still proceed with their case without using these statements in their case-in-chief. In the Fourth Amendment context, however, the case is usually dismissed if the prosecutor cannot use the physical evidence in his case-in-chief. Therefore, in the Fourth Amendment arena, the exclusionary rule gives police officers a reason to obey the law, whereas in the Fifth Amendment situation, it does not.

${ }^{194}$ We are, in fact, in some danger of reexperiencing this same Fourth Amendment lawlessness today. The Court has deconstitutionalized the Fourth Amendment's exclusionary rule as well, holding that it is no longer a constitutionally required remedy but merely a method to deter improper police behavior. See Ruth W. Grant, The Exclusionary Rule and the Meaning of Separation of Powers, 14 HARV. J.L. \& PuB. POL'Y 173, 193-96 (1991) (arguing that under a unitary model of criminal prosecution the exclusionary rule is constitutionally required by the Fourth Amendment and due process); see also Stone v. Powell, 428 U.S. 465, 484-86 (1976). Thus, the Court's source of authority for imposing the exclusionary rule on the states is of dubious origin.

${ }_{195}$ See supra notes $172-74$.

${ }^{196}$ Actually, there is a partial remedy for those who are charged-the exclusion of the statement from the prosecutor's case-in-chief. See supra note 186 (noting a case in which this exclusionary rule was recognized). Even this inadequate remedy, however, is unavailable to uncharged suspects.

197 One commentator posits that courts are opposed to the frequent unfairness of money damages in $\S 1983$ suits and suggests that unlawful police practices are better resolved by injunctions against police departments. See Christina Whitman, Constitutional Torts, 79 MICH. L. REV. 5, 60 (1980) (arguing that individual officials may only be following orders of superiors, thus it makes more sense to blame the government institution and force it to change). Presently, "the inadequacy of police training may serve as the basis for $\$ 1983$ liability only where the [municipality's] failure to train [its officers properly] amounts to deliberate indifference to the rights of persons with 
Although in a civilized society reasoned considerations of justice should apply to all members equally, there is visceral appeal in protecting those innocent of wrongdoing. By most accounts, only fifty percent of those arrested (and presumably interrogated) are convicted. ${ }^{198}$ While many of these releases may be due to insufficient evidence or procedural or witness-related problems rather than actual innocence, surely some number of truly innocent people get caught in this net. For those who do not go to trial for the crime about which they were interrogated, "it is damages or nothing." 199

\section{Maintaining Miranda's Symbolic Value}

Miranda is symbolic of our societal commitment to the Constitution and to criminal procedural guarantees; ${ }^{200}$ it accomplishes this

whom the police come into contact," and this policy causes a constitutional injury to a plaintiff. City of Canton v. Harris, 489 U.S. 378, 388 (1989). In order to have a viable $\$ 1983$ claim against a municipality, however, a state actor must first commit an underlying constitutional violation. See Monell v. Dep't of Social Servs., 436 U.S. 658,691 (1978) ("Congress did not intend municipalities to be held liable unless action pursuant to official municipal policy of some nature caused a constitutional tort."). Thus, a municipality currently cannot be held liable for a Miranda violation committed by one of its officers.

In any case, even where the police department or municipality can be held responsible for a constitutional violation, the remedy is generally limited to damages rather than injunctive relief. See, e.g., City of Los Angeles v. Lyons, 461 U.S. 95, 105 (1983) (reversing the grant of an injunction against the Los Angeles police department for the use of "chokeholds" due to the lack of evidence suggesting that the civil rights plaintiff would again be arrested and subjected to a chokehold).

${ }^{198}$ See Brian Forst, Criminal Justice System: Measurement of Performance, 2 ENCYCLOPEDIA OF CRIME AND JUSTICE 479, 481 (Sanford H. Kadish ed., 1983) (noting that the conviction rate is approximately $50 \%$, based on the ratio of convictions to arrests, including cases that are unworthy of prosecution); see also YALE KAMISAR ET al., MOdern CRIMINal Procedure: CASES, Comments ANd Questions 12 (7th ed. 1990) (" $[\mathrm{T}]$ he cases against $30-50 \%$ of all arrestees will be dropped as a result of [prosecutorial] screening.").

${ }^{199}$ Bivens v. Six Unknown Named Agents of Fed. Bureau of Narcotics, 403 U.S. 388,410 (1971) (Harlan, J., concurring).

${ }^{200}$ See Caplan, supra note 28, at 1471. Caplan has stated:

For its supporters, Miranda is a gesture of government's willingness to treat the lowliest antagonist as worthy of respect and consideration. They have a point. There is something attractive about a legal system that insists that suspects have a right to refuse to answer police inquiries, that imposes on the police an obligation to communicate that right, and that provides counsel to the indigent. The Fifth Amendment, as much as any constitutional provision, illustrates that ours is a limited government. It reflects an historic distrust of authority. 
with very little cost in terms of lost convictions. ${ }^{201}$ In fact, although a number of studies show a reduction in statements obtained during custodial interrogation immediately following the implementation of the Miranda rules, ${ }^{202}$ various other authors refute these statistics. More recent empirical analyses show no decrease in the overall number of convictions. ${ }^{203}$ Allowing a federal cause of action under $\S 1983$ for a violation of the Miranda warnings would signify a federal commitment to Fifth Amendment values. $^{204}$ In fact, given the permeation of these warnings in American popular culture, a failure to offer a civil rights action itself sends out a loud and definitive message.

Moreover, this symbolism is not lost on police officers, who, of course, are subject to the same cultural messages as other citizens. As noted by Professor Dripps, who is no fan of the privilege:

${ }^{201}$ See Schulhofer, supra note 28 , at 460 (" $[\mathrm{A}] \mathrm{s}$ things have turned out, Miranda did accomplish something, and it did so at surprisingly little cost."). One author has suggested that an empirical study be conducted to assess the effect that expanded $\S 1983$ liability would have on state and local governments. See Beermann, supra note 71 , at 95 (suggesting that empirical evidence is necessary to enable courts to balance the competing interests of maximizing compensation to the victim and of allowing law enforcement officers to perform effectively, lest judges look to their own political views).

${ }_{202}$ See, e.g., DEPARTMENT OF JUSTICE REPORT, supra note 7, at 511 n.218; Controlling Crime Through More Effective Law Enforcement: Hearings before the Subcomm. on Criminal Laws and Procedures of the Senate Comm. on the Judiciary, 90th Cong., 1st Sess. 200-01, 204-06 (1967) (describing Philadelphia study finding that refusal to make a statement increased from 32\% to 59\% after Miranda); $i d$. at 1120, 1123 (describing New York study finding that percentage of non-homicide felony cases presented to grand juries involving admissions fell from $49 \%$ to $15 \%$ following Miranda); Richard $\mathrm{H}$. Seeburger \& R. Stanton Wettick, Jr., Miranda in Pittsburgh-A Statistical Study, 29 U. PrTT. L. REv. 1,11 (1967) (finding a $16.9 \%$ decline in the confession rate).

${ }^{203}$ See Liva BaKer, Miranda: Crime, LAW and Poltrics 180-81, 403-05 (1983) (describing summaries of studies that found decreasing confession rates for the first year or so after the Miranda ruling but found that conviction rates returned to their former levels one year later); see also ABA SPECIAL COMM. ON CRIMINAL JUSTICE IN A Free SoC'Y, CRIMINAL JUSTICE IN CRISIS 5 (1988) (finding that Miranda did not "significantly handicap police and prosecutors in their efforts to arrest, prosecute, and obtain convictions"); Kamisar, supra note 28, at 585 n.164 (listing empirical studies on the impact of Miranda).

${ }^{204}$ As Professor Whitman noted,

[T] ] function of a "supplementary" federal cause of action under section 1983, and of allowing plaintiffs to pursue such action in federal court, is largely symbolic. But symbolism is important in our federal system, where the lines between nation and state are significant but difficult to define. Even where state relief exists it makes a great deal of sense to provide a federal cause of action, and federal jurisdiction, in order to affirm those rights that the federal government believes to be of special importance.

Whitman, supra note 197, at 24 . 
[T]he warnings have contributed generally to a more humane police culture, and they surely impose some limits on police tactics in specific cases. The reading of rights affects the questioner, even if it glances off the suspect. Only a corroded conscience could live with reading the Miranda card by the glare of the arc lamp. And the law-abiding police interrogator must tread rather lightly; too much pressure and the suspect may invoke the right to counsel. ${ }^{205}$

Finally, Miranda's exclusionary rule is a symbol of the Court's refusal to condone the unlawful conduct that produced the confession. This "judicial integrity" rationale posits that a court ought to nullify a constitutional violation rather than admit the evidence and thereby permit the government to profit by its wrongdoing. Such denial of court assistance in perpetuating the violation is necessary to maintain respect for the Constitution and to preserve the judicial process.

\section{Proposed SOLUTIONS}

An extensive scholarly debate has taken place regarding the legitimacy of Miranda's prophylactic rules in particular and of prophylactic rules in general. The resolution of this debate in favor of legitimacy and a reconstitutionalization of such rules would be the best method for protecting the Self-Incrimination Clause. It would allow a $\S 1983$ action based upon a Miranda violation or involuntary confession and put to rest the Article III legitimacy concerns that arise when federal courts overturn state court criminal convictions based upon Miranda violations. I will discuss this option last.

Other methods for accomplishing this objective without overturning Supreme Court precedent include refining the law surrounding substantive due process and Fourth Amendment

${ }^{205}$ Donald A. Dripps, Beyond the Warren Court and Its Conservative Critics: Toward a Unified Theory of Constitutional Criminal Procedure, 23'U. MICH. J.L. REF. 591, 632 (1990) (footnote omitted). "But those concerned with official abuse of the innocent will not wage war against Miranda. If the alternative to Miranda is the old voluntariness test, they will count themselves among Miranda's staunch supporters." Id. at 634 (footnote omitted); see also Welsh S. White, Defending Miranda: A Reply to Professor Caplan, 39 VAND. L. REV. 1, 21-22 (1986) ("Miranda's symbolic value not only has produced a better atmosphere for people who come in contactivith the police but also may have made a tangible contribution toward curbing abusive police practices.... [O]verruling Miranda would convey the message that restraints on police interrogation have been largely abandoned."). 
jurisprudence. The latter two solutions, while not as promising or encompassing, would eliminate the primary obstacles to basing a $\$ 1983$ action on the Fifth Amendment-that the Self-Incrimination Clause cannot be violated until the statement is used in court and that police officers are not the proximate cause of the admission of such evidence.

\section{A. The Due Process Clause}

One potential solution to the deconstitutionalization of Miranda is to concede, as argued in this Article, that neither the Miranda decision nor the Fifth Amendment's Self-Incrimination Clause provides the basis for a $\S 1983$ action, and instead turn to the Due Process Clause of the Fourteenth Amendment for guidance.

This was the path chosen by the Cooper II court, which adopted the theory that substantive due process "flatly prohibits coercion in the pursuit of a statement." 206 This theory is flawed, however, because it fails to distinguish between substantive and procedural due process, and it fails to distinguish between the standard for finding a confession to be involuntary and the standard for finding a substantive due process violation. Most, if not all, coerced confession cases are procedural due process cases. ${ }^{207}$ The process that is due a defendant before a State can deprive her of liberty through a criminal conviction is a fair trial. ${ }^{208}$ A fair trial is one that, among other things, is free of coerced confessions. Nothing in the Constitution prohibits the taking of the confession. In fact, the Government can compel statements in many circumstances; it simply cannot use them against the speaker in a criminal proceeding. ${ }^{209}$ Consequently, most trial and trial-related rights contained

${ }^{206}$ Cooper II, 963 F.2d 1220, 1244 (9th Cir.) (en banc), cert. denied, 113 S. Ct. 407 (1992).

${ }^{207}$ These cases hold that a due process violation occurs not when the confession is taken but when it is used in court. See, e.g., Haynes v. Washington, 373 U.S. 503, 516 (1963) (determining "whether the circumstances under which the confession was made were such that its admission into evidence amounts to a denial of due process") (emphasis added) (footnote omitted); Spano v. New York, 360 U.S. 315, 315 (1959) (presenting the question of whether the defendant's "confession was properly admilted into evidence under the Fourteenth Amendment") (emphasis added). Furthermore, these cases never used the words "substantive due process."

${ }^{208}$ See, e.g., Daniels v. Williams, 474 U.S. 327, 337 (1986) (Stevens, J., concurring) (" $[\mathrm{I}] \mathrm{t}$ is a guarantee of fair procedure, sometimes referred to as 'procedural due process': the State may not execute, imprison, or fine a defendant without giving him a fair trial ....").

${ }^{209}$ See Kastigar v. United States, 406 U.S. $441,448-49$ (1972) (holding that it is 


\section{in the Fifth, Sixth, and Fourteenth Amendments are procedural} rights, mandating what steps a State must take before incarcerating an individual. ${ }^{210}$

Substantive due process, on the other hand, protects a right deemed to be so "fundamental" that the State cannot deprive an individual of it without a compelling justification, which in practice generally means that no procedure will suffice to allow the deprivation. ${ }^{211}$ The best known modern examples in which state police

appropriate to compel testimony if speaker is granted immunity); see also New York v. Quarles, 467 U.S. 649, 664 (1984) (O'Connor, J., concurring) ("Miranda has never been read to prohibit the police from asking questions to secure the public safety. Rather, the critical question Miranda addresses is who shall bear the cost of securing the public safety when such questions are asked and answered: the defendant or the State.").

${ }^{210}$ See, e.g., Coy v. Iowa, 487 U.S. 1012, 1012-20 (1988) (holding that a defendant in state criminal proceedings has a Sixth Amendment right to confront adverse witnesses, as the Confrontation Clause is essential to the fairness of trial and ensures the integrity of the fact-finding process); Taylor v. Illinois, 484 U.S. 400, 408 (1988) (holding that a defendant has a right to present witnesses in her own defense under the Compulsory Process Clause of the Sixth Amendment); Strickland v. Washington, 466 U.S. 668, 687 (1984) (noting that a defendant has a right to effective assistance of counsel); In re Winship, 397 U.S. 358, 363 (1970) (holding that proof beyond a reasonable doubt in criminal proceedings is required by fundamental fairness inherent in the Due Process Clause to ensure presumption of innocence and reduce risk of convictions resting on factual error); Duncan v. Louisiana, 391 U.S. 145, 149 (1968) (declaring that the right to jury trial is fundamental to the American scheme of justice); Brady v. Maryland, 373 U.S. 83, 87 (1963) (finding a due process right to have the prosecutor disclose material exculpatory evidence); Gideon v. Wainwright, 372 U.S. 335, 344 (1963) (holding that an indigent defendant in a criminal trial has a fundamental right to assistance of counsel).

${ }^{211}$ Although the Due Process Clause originally and literally protected only the procedure by which a state may deprive an individual of liberty or property, the Court has also used it to scrutinize the substance of state statutes. See, e.g., Pierce v. Society of Sisters, 268 U.S. 510, 534 (1925) (striking down an Oregon statute that required all children ages eight through sixteen to attend public rather than parochial schools as a violation of parents' liberty interest in raising and educating their children); Meyer v. Nebraska, 262 U.S. 390, 403 (1923) (striking down a Nebraska statute that prohibited the teaching of foreign languages to any child below grade eight as a violation of teachers' liberty interest in practicing their profession, children's liberty interest in acquiring knowledge, and parents' liberty interest in supervising their offspring); Lochner v. New York, 198 U.S. 45, 64 (1905) (striking down a New York statute that prohibited the employment of bakery workers for more than 60 hours per week as a violation of citizens' liberty interest in employment).

In response to the perceived evil of the Lochner era, which allowed the Court to act as a "super-legislature," the Court limited substantive due process to individual rights either (1) specifically contained in the language of the Constitution itself, generally the first eight amendments, or (2) otherwise deemed by the Court to be "fundamental." Thus, while civil rights actions against state actors may be termed due process or even substantive due process violations, most are actually violations of a more specific constitutional provision incorporated into the Fourteenth Amendment, 
action was censured by the Supreme Court on what has been interpreted to be substantive due process grounds involved torture ${ }^{212}$ and stomach pumping. ${ }^{213}$ Where a substantive due process violation is found, a plaintiff may invoke $\S 1983$ regardless of the availability of a state remedy, for "the constitutional violation is complete as soon as the prohibited action is taken." ${ }^{214}$ In many cases, however, although there is a deprivation of a recognized

and thus fit into category (1). In this section of the Article, all references are to category (2), which I will call "pure" substantive due process rights. These rights are not specifically mentioned in any constitutional clause. Pure substantive due process can be violated by either legislative enactments, as in Roe v. Wade, 410 U.S. 113, 153 56 (1973) (striking down a Texas statute that prohibited abortions as violative of the right to privacy), or by nonlegislative executive action, as in Rochin v. California, 342 U.S. 165, 174 (1952) (overturning criminal conviction for possession of morphine based on evidence obtained through forcible pumping of defendant's stomach).

The Court itself has distinguished between what I call "pure" substantive due process and procedural due process as follows:

So-called "substantive due process" prevents government from engaging in conduct that "shocks the conscience," Rochin v. Califormia, 342 U.S. 165, 172 (1952), or interferes with rights "implicit in the concept of ordered liberty," Palko v. Connecticut, 302 U.S. 319, 325-326 (1937). When government action depriving a person of life, liberty, or property survives substantive due process scrutiny, it must still be implemented in a fair manner. Matthew $v$. Eldridge, 424 U.S. 319, 335 (1976). This requirement has traditionally been referred to as "procedural" due process.

United States v. Salerno, 481 U.S. 739, 746 (1987).

${ }^{212}$ See, e.g., Brown v. Mississippi, 297 U.S. 278 (1936). In this case, the Court stated that the criminal convictions based upon confessions obtained by severely whipping the defendants offended the fundamental traditions and conscience of society and that the trial based upon this unreliable evidence was a farce. Nevertheless, the Court's holding in Brown v. Mississippi was merely that "the use of the confessions . . . obtained [through physical torture] as the basis for conviction and sentence was a clear denial of due process." Id. at 286 (emphasis added).

${ }^{213}$ See Rochin, 342 U.S. at 172-73 (stating that state court conviction cannot be secured by methods that shock the conscience). It is far from clear, however, that this was actually a substantive due process case. It is clear that it would not be one today. Rochin was decided after the Fourth Amendment was incorporated into the Fourteenth and made applicable to state court criminal proceedings in Wolf $\mathrm{v}$. Colorado, 338 U.S. 25 (1949), but before the exclusionary rule was made mandatory in state criminal proceedings in Mapp v. Ohio, 367 U.S. 643 (1961) (overruling Wolf). The Court noted the anomaly that if Mr. Rochin had been forced to confess, his statement would be excluded, but when an equal amount of force was used against him to secure physical evidence, such evidence was admitted. The Court turned to the general notion of justice embodied in the Due Process Clause because it had nowhere else to turn.

If Rochin were brought today, of course, the Court would exclude the evidence pursuant to the Fourth Amendment's exclusionary rule. Both today and in 1952, Mr. Rochin had a valid $\$ 1983$ action based upon a Fourth Amendment violation, which occurred when his stomach was pumped, not when the evidence was introduced.

${ }^{214}$ Daniel v. Williams, 474 U.S. 327, 338 (1986) (Stevens, J., concurring). 
property or liberty interest, the Court has held that the procedure due is merely to disallow any evidence obtained by these deprivations in court or to provide a state tort or criminal law remedy. Thus, in most due process cases, a $\$ 1983$ claim is not stated. ${ }^{215}$ In other words, unlawful conduct by state officials does not rise to the level of a substantive due process violation. Most reasonable persons would agree, however, and recent Supreme Court cases concerning the Fourth and Eighth Amendments hold, that in the case of actual police brutality, the "constitutional line" has been crossed, and, therefore, a $\S 1983$ action is available, regardless of alternative remedies. ${ }^{216}$

Due to the subjective nature of the test used to establish a violation of substantive due process and the lack of definition as to the contours of the right, there is no objective method for determining when any particular action has crossed this roving "constitutional line. ${ }^{n 217}$ To determine if a state actor's conduct that coerces a

${ }^{215}$ See, e.g., Parratt v. Taylor, 451 U.S. 527, 543-44 (1981) (noting that although respondent prisoner was deprived of property under color of law, he did not sufficiently allege a violation of the Due Process Clause of the Fourteenth Amendment to state a claim under $\S 1983$ because Nebraska had a tort claim procedure that provided an adequate post-deprivation remedy), overruled on other grounds by Daniel, 474 U.S. 327 (1986); Ingraham v. Wright, 430 U.S. 651, 676-80 (1976) (observing that although personal security is a liberty interest protected by the Fourteenth Amendment, plaintiffs had no $\$ 1983$ action against their public school teacher for corporal punishment delivered without a prior disciplinary hearing because the plaintiffs have a state tort damage claim and defendant may be subject to state criminal penalties if that punishment is later found to be excessive); Paul v. Davis, 424 U.S. 693, 701 (1976) (holding that a citizen's liberty interest in preserving his or her reputation is insufficient to trigger the protection of the Due Process Clause to support a $\$ 1983$ action in a case where police circulated a picture of the plaintiff along with his name and the words "active shoplifter"); Rogers v. Richmond, 365 U.S. 534, 540-41 (1961) (stating that due process prohibits the admission of involuntary confessions and requires the reversal of state convictions based upon such admissions).

${ }_{216}$ No procedure would justify the unnecessary beating of an arrestee by the police or of a convicted prisoner by a guard. See Hudson v. McMillian, 112 S. Ct. 995, 1000 (1992) (holding that malicious and sadistic punching and kicking of handcuffed convicted prisoner by state guards would violate Eighth Amendment despite the fact that the inmate did not suffer any serious injuries as a result); see also Graham v. Connor, 490 U.S. 386, 395 (1989) (holding that unreasonable use of excessive force in effectuating arrest would violate Fourth Amendment). Because specific constitutional provisions are violated at the time of the state action in such cases, those plaintiffs are not invoking procedural due process. Thus, the court did not consider whether postdeprivation tort remedies provided adequate procedural protection. In my opinion, it would be ludicrous to say that while arrestees and convicted prisoners are protected from physical abuse by state actors, post-arrest, preconviction citizens living in states that provide alternative tort remedies for such beatings would not be protected by $\S 1983$.

${ }^{217}$ For an interesting discussion on this point, see Richard H. Fallon, Jr., Some 
confession violates substantive due process, then, one must first decide whether his actions are as egregious as police brutality, so that the Court's conscience is shocked and a $\$ 1983$ action is appropriate, or whether his conduct is something less, perhaps more akin to state-sponsored defamation, corporal punishment, or the violation of a procedural rule, such that either the court's conscience is not shocked and/or a state tort action or suppression ruling is all the procedure due the affected individual. ${ }^{218}$

In addition to the few courts that have found a substantive due process violation in the confession context, ${ }^{219}$ some circuit courts have found substantive due process violations where police action-or inaction where the state had an affirmative duty to act-compromised an individual's right to "bodily integrity." 220

Confusions About Due Process, Judicial Review, and Constitutional Remedies, 93 Colum. L. REV. 309, 324 (1993) (noting that "no agreed framework has emerged for identifying when relatively isolated official acts offend substantive due process," although " $[t]$ he Court has established that conscience-shocking action violates due process" ${ }^{n}$.

${ }^{218}$ For example, in Ingraham, the Court ruled only on the Eighth Amendment and procedural due process claims, leaving open the possibility of bringing a $\$ 1983$ substantive due process claim on the same facts. See Ingraham, 430 U.S. at 679 n.47 ("We have no occasion in this case ... to decide whether or under what circumstances corporal punishment of a public school child may give rise to an independent federal cause of action to vindicate substantive rights under the Due Process Clause."); see also id. at 689 n.5 (White, J., dissenting) (arguing that the Court should amend the grant of certiorari and set the case for reargument on a substantive due process theory). Likewise, in a concurring opinion criticizing the Parratt Court's reliance on procedural due process, Justice Powell noted that " $t$ ] he Due Process Clause imposes substantive limitations on state action, and under proper circumstances these limitations may extend to intentional and malicious deprivations of liberty and property, even where compensation is available under state law." Parratt, 451 U.S. at 552-53.

${ }^{219}$ See, e.g., Cooper II, 963 F.2d 1220, 1249 (9th Cir.) (en banc), cert. denied, 113 S. Ct. 407 (1992); Rex v. Teeples, 753 F.2d 840, 843 (10th Cir.), cert. denied, 474 U.S. 967 (1985); Duncan v. Nelson, 466 F.2d 939, 944 (7th Cir.), cert. denied, 409 U.S. 894 (1972). See generally supra notes $141-70$ and accompanying text.

${ }^{220}$ See, e.g., Temkin v. Frederick County Comm'rs, 945 F.2d 716, 723 (4th Cir. 1991) (holding that a police officer who severely injured an innocent driver during a high-speed chase did not violate substantive due process because his conduct, although "lacking in judgment, [fell] short of the 'shocks the conscience' standard"), cert. denied, 112 S. Ct. 1172 (1992); Pittsley v. Warish, 927 F.2d 3, 7 (1st Cir.) (holding that a police officer's refusal to let two young children kiss their stepfather before he was taken into custody, although "despicable and wrongful," did not "shock the consciencen), cert. denied, 112 S. Ct. 226 (1991); Wood v. Ostrander, 879 F.2d 583, 588, 595-96 (9th Cir. 1989) (holding that a police officer who acted with deliberate indifference by impounding the plaintiff's car and then leaving her "by the side of the road at night in a high-crime area" violated substantive due process where the plaintiff was ultimately raped as a result of the defendant's carelessness), cert. denied, 
The Supreme Court has likewise offered the possibility of $\S 1983$ actions based upon substantive due process in cases involving the loss of personal security or liberty. ${ }^{221}$

I suggest that the taking of a confession that is actually involuntary, and not just in contravention of Miranda, would violate procedural due process if used in court, but in many instances would not so shock the conscience of the court that substantive due process would be violated at the time the confession was taken. ${ }^{222}$ The interrogation of a suspect does constrain his liberty, but it is not taking liberty without due process so long as the officer had a warrant or probable cause to arrest. ${ }^{223}$ In fact, it is the officer's

498 U.S. 938 (1990); Metzger v. Osbeck, 841 F.2d 518, 520 (3d Cir. 1988) (holding that a public school teacher's decision to discipline a student, "if accomplished through excessive force and appreciable physical pain," may violate substantive due process if the teacher acted with the intent to cause harm); Checki v. Webb, 785 F.2d 534, 538 (5th Cir. 1986) (indicating that a police officer who intentionally threatened a suspect with his vehicle might violate substantive due process if his actions "amounted to an abuse of official power that shocks the conscience"); White v. Rochford, 592 F.2d 381, 383 (7th Cir. 1979) (holding that a police officer's refusal to help three small children left alone in an automobile after the officer arrested the driver amounted to a deprivation of substantive due process "where that refusal ultimately result[ed] in physical and emotional injury to the children").

${ }^{221}$ See, e.g., Herrera v. Collins, 113 S. Ct. 853, 876, 878-79 (1993) (Blackmun, J., dissenting) (arguing that the execution of an innocent defendant is an arbitrary imposition on liberty which shocks the conscience); Foucha v. Louisiana, $112 \mathrm{~S}$. Ct. 1780, 1809 (1992) (Thomas, J., dissenting) (arguing that legislation permitting continued confinement of an insanity acquitee until she can demonstrate that she poses no danger to society does not shock the conscience); Collins v. Harker Heights, 112 S. Ct. 1061, 1070 (1992) (holding that city's failure to train or warn its employees about known hazards beneath the city streets, resulting in death by asphyxia in a manhole, was not sufficiently arbitrary or conscience-shocking to violate substantive due process); DeShaney v. Winnebago County, 489 U.S. 189, 197 (1989) (holding that substantive due process guarantee against state deprivation of safety and security does not apply to social workers who have no affirmative constitutional duty to prevent a parent from abusing her child, even where state employees receive numerous reports of abuse); United States v. Salerno, 481 U.S. 739, 746 (1987) (holding that the Bail Reform Act of 1984 that authorizes pretrial detention is not punishment before trial but rather a permissible regulation preventing danger to community); Youngberg $v$. Romeo, 457 U.S. 307, 324 (1982) (holding that involuntarily committed patients at state mental institution had a substantive due process interest in reasonably safe conditions of confinement, freedom from bodily restraints, and minimally adequate training).

${ }_{222}$ The Fourteenth Amendment provides procedural protection by disallowing the confession at trial. Furthermore, certain state tort remedies such as false imprisonment, intentional infliction of emotional distress, and assault and battery may be available, depending on how the confession is secured.

223 The Court has stated that the deprivation of liberty occasioned by an arrest does not trigger the strict judicial scrutiny of substantive due process because the system provides adequate procedural controls such as warrants and judicial 
job to attempt to secure a confession. ${ }^{224}$ Furthermore, the standard for finding a confession to be involuntary is much lower than the "shock the conscience" substantive due process standard used by the Cooper II and most other courts. Although some coercion by the interrogating officer is required, ${ }^{225}$ a confession can be rendered involuntary because of the particular susceptibility of the suspect, for example his youth, education level, and physical characteristics. ${ }^{226}$ Thus, in certain cases, a very small amount of pressure may result unforeseeably in an involuntary confession.

Of course, in some instances the coercion becomes so acute that it is indistinguishable from police brutality, such as when an officer literally beats a confession out of a suspect. At that point, the state action shocks the conscience and should be deemed a constitutional violation capable of supporting a $\$ 1983$ action, whether or not the resulting confession is ever used in court. I submit that such a point was not reached in the Cooper case, as Mr. Cooper's will was never overborne (he never confessed), and no physical or unusual psychological pressure was used.

In addition to the legal flaws outlined above, the following problems are worth noting. The Supreme Court highly disfavors expanding the reach of substantive due process. ${ }^{27}$ In isolating a

determinations of probable cause. See, e.g., Ingraham v. Wright, 430 U.S. 651, 679-80 (1977).

${ }^{224}$ The Court has acknowledged society's "need for police questioning as a tool for the effective enforcement of criminal laws. Without such investigation, those who were innocent might be falsely accused, those who were guilty might wholly escape prosecution, and many crimes would go unsolved." Schneckloth v. Bustamonte, 412 U.S. 218, 225 (1973) (citation omitted).

Although the Cooper II court was shocked by the police plan to violate Miranda in order to obtain statements that they could use to keep the defendant off the stand and to deprive him of a potential insanity defense, the Supreme Court has blessed this precise use of statements taken in violation of Miranda. Indeed, statements taken in violation of Miranda are regularly used this way in our criminal justice system with no constitutional consequences. See supra notes 45-57 and accompanying text. Thus, these police officers were simply making clever use of Supreme Court decisions that specifically permitted their behavior.

${ }^{225}$ See Colorado v. Connelly, 479 U.S. 157, 167 (1986) (holding that "coercive police activity is a necessary predicate to the finding that a confession is not 'voluntary' within the meaning of the Due Process Clause").

${ }_{226}$ See, e.g., Arizona v. Fulminante, 111 S. Ct. 1246, 1252 n.2 (1991); Schneckloth v. Bustamonte, 412 U.S. at 226 (1972) (listing some of the factors that the Court has considered in determining whether a confession was truly voluntary, including "the youth of the accused, his lack of education, [and] his low intelligence") (citation omitted).

${ }^{227}$ See, e.g., Collins v. City of Harker Heights, 112 S. Ct. 1061 (1992). In Collins, the Court stated: 
constitutional violation in any $\S 1983$ suit, the Court rightly favors the use of specific provisions in the Bill of Rights over more general notions of the Fourteenth Amendment's Due Process Clause. ${ }^{228} \mathrm{~A}$ substantive due process claim, basically a claim that one was treated in a thuggish manner, is much narrower than a Fifth Amendment Self-Incrimination Clause claim. Since the Fifth Amendment's SelfIncrimination Clause was not violated, it appears disingenuous to bootstrap the compelled statement claim through a substantive due process analysis.

The second, more practical disadvantage with a substantive due process approach is that the Court will be required to engage in the same case-by-case analysis it used to determine the voluntariness of pre-Miranda confessions. Of course, the Court may still, under certain circumstances, be required to determine actual voluntariness, but Miranda provides the convenient presumption that the confession was voluntary (if followed) or involuntary (if not followed). Determining voluntariness is extremely difficult without the aid of the presumption and constitutes an unmanageable drain on judicial resources. ${ }^{229}$

Moreover, deeming all involuntary confessions to be violative of substantive due process would provide insufficient guidance to police as to what constitutes acceptable behavior, an issue that was resolved by Miranda's bright-line rule prior to its deconstitutionalization. As a result, police may cease all custodial interrogation rather than run the risk of being found civilly liable. For example, the Court's most recent holding that a confession was involuntary was premised, in part, on the Court's finding that the defendant possessed low-average to average intelligence, dropped

As a general matter, the Court has always been reluctant to expand the concept of substantive due process because [the] guideposts for responsible decisionmaking in this unchartered area are scarce and open-ended. The doctrine of judicial self-restraint requires us to exercise the utmost care whenever we are asked to break new ground in this field.

Id. at 1068 (citation omitted); see also Bowers v. Hardwick, 478 U.S. 186, 195 (1986) ("There should be ... great resistance to expand the substantive reach of ... [the Due Process Clause], particularly if it requires redefining the category of rights deemed to be fundamental.").

${ }^{228}$ See Graham v. Connor, 490 U.S. 386, 395 (1989) (holding that "all claims that law enforcement officers have used excessive force . . . in the course of an arrest ... should be analyzed under the Fourth Amendment and its 'reasonableness' standard, rather than under a 'substantive due process' approach").

${ }^{229}$ Additionally, substantive due process would apply only if there were actual coercion, not a mere denial of Miranda. This theory would fail to offer a $\$ 1983$ cause of action for a Miranda violation, even if done purposefully. 
out of school in the fourth grade, was short of stature and slight of build, and had not in the past adapted well to the stress of prison life. ${ }^{230}$ The Court also found that an informant's position as defendant's friend might well have made the defendant particularly susceptible to the informant's entreaties. ${ }^{231}$ These are factors which the police officer cannot control and of which she may have no knowledge at the time of the interrogation. Thus the officer will be unable to predict whether a judge, having before her all of the appropriate information, will subsequently determine that the confession was involuntary. It would be unfair to hold this officer liable for money damages, then, based solely upon this confession. I suggest that Miranda's bright-line rule is necessary so that police know at the time of the interrogation exactly what procedure to follow.

The only method I can envision that would allow a $\S 1983$ action, while escaping some of the problems with this analysis, is a less rigorous substantive due process test that nonetheless provides guidance to police officers. Presently, the standard to determine whether substantive due process is violated changes depending upon the circuit, who the victim is, who the violator is, and the circumstances surrounding the violation. ${ }^{232}$ The Supreme Court may countenance the use of a less stringent standard by analogy to the language in cases holding that the government owes a greater duty to those people whom the State has deprived of their liberty. For example, there is no state duty to protect children from parental abuse $^{233}$ or to provide safe working conditions to city employees. ${ }^{234}$ However,

${ }^{230}$ See Arizona v. Fulminante, 111 S. Ct. 1246, 1252 n.2 (1991).

${ }^{231}$ See id. The Court's holding was also based on the findings that the defendant was in danger of physical harm at the hands of other inmates and that the FBI informant promised to protect him upon condition that he confess.

${ }^{232}$ Compare Cooper II, 963 F.2d 1220, 1248 (9th Cir.) (en banc), cert. denied, 113 S. Ct. 407 (1992) (using Rochin's "shocks the conscience" test); Temkin v. Frederick County Comm'rs, 945 F.2d 716, 720 (4th Cir. 1991) (applying "shocks the conscience" standard in police pursuit cases), cert. denied, 112 S. Ct. 1172 (1992) and Checki v. Webb, 785 F.2d 534, 538 (5th Cir. 1986) (applying "shocks the conscience" test where police officer intentionally used his car to terrorize motorist) with Fagan v. City of Vineland, 22 F.3d 1283, 1292 (3d Cir. 1994) (applying relatively lenient "deliberate indifference" test in an action against a city's allegation of a substantive due process violation in a police pursuit case).

${ }^{233}$ See DeShaney v. Winnebago County Dep't of Soc. Servs., 489 U.S. 189, $197-98$ (1989) (rejecting the argument that the State acquired an affirmative duty, enforceable through the Due Process Clause, to protect a child from his father).

${ }^{234}$ See Collins v. City of Harker Heights, 112 S. Ct. 1061, 1065 (1992) (rejecting 
the State owes a duty to take care of those who have already been deprived of liberty. [The Court has] held, for example that . . . the Due Process Clause of its own force requires that conditions of confinement satisfy certain minimal standards for pretrial detainees, for persons in mental institutions, for convicted felons, and for persons under arrest. ${ }^{235}$

Those being interrogated thus deserve a higher degree of protection from the State because their liberty has been curtailed by it. The corresponding duty of the State may be to provide Miranda rights to all suspects or at least to refrain from intentionally ignoring a suspect's request for an attorney or to remain silent.

Such a solution would overcome virtually all of the obstacles to enforcement noted in Part II of this Article. Substantive due process is a constitutional requirement, not a prophylactic rule, and is violated immediately regardless of later court use of any evidence collected via the violation. The offending officer's actions would be under color of law when committed and would be the proximate cause of the plaintiff's injury. While use of this legal theory would permit a damage claim as well as exclusion of any evidence collected as a result of the violation from the prosecutor's case-in-chief, it would probably mandate exclusion of all collateral uses of this evidence as well.

\section{B. The Fourth Amendment}

The Court has held that all § 1983 claims that law enforcement officers used excessive force in the course of an arrest, investigatory stop, or other seizure are properly analyzed under the Fourth Amendment, not substantive due process. ${ }^{236}$ The standard for determining whether a Fourth Amendment violation has occurred is an objective one: whether the officer's actions were "objectively

the argument that the city's failure to train or warn its employees about known workplace hazards violated due process).

${ }^{235} \mathrm{Id}$. at $1069-70$ (citations omitted).

${ }^{236}$ See Graham v. Connor, 490 U.S. 386, 395 (1989) (holding that a claim of excessive force in effectuating arrest was properly analyzed under the Fourth Amendment, which provides "an explicit textual source of constitutional protection against" physically intrusive governmental conduct, rather than the "more generalized notion of 'substantive due process'"); see also Ward v. City of San Jose, 967 F.2d 280, 284 (9th Cir. 1991) ("'[U]nder Graham, excessive force claims arising before or during arrest are to be analyzed exclusively under the [F]ourth [A]mendment's reasonableness standard rather than the substantive due process standard ....') (quoting Reed v. Hoy, 909 F.2d 324, 329 (9th Cir. 1989), cert. denied, 501 U.S. 1250 (1991)). 
reasonable." ${ }^{237}$ This standard is much more lenient to the plaintiff than the substantive due process or Eighth Amendment standards for excessive force, which require that the plaintiff prove both that the officer's actions were not objectively reasonable and that such officer acted with a certain subjective mental state. ${ }^{238}$ The Court, however, has not resolved the question whether the Fourth Amendment's prohibition against excessive force continues to protect individuals where arrest ends and pretrial detention begins. ${ }^{239}$ The circuit courts have likewise not resolved the issue

${ }^{237}$ Graham, 490 U.S. at 396-97, 399 (noting that the Fourth Amendment "reasonableness" inquiry is "whether the officers' actions are 'objectively reasonable' in light of the facts and circumstances confronting them, without regard to their underlying intent or motivation").

${ }^{288}$ The Graham Court rejected, for purposes of Fourth Amendment analysis, Judge Friendly's four-part substantive due process test developed in Johnson v. Glick, 481 F.2d 1028, 1033 (2d Cir.), cert. denied, 414 U.S. 1033 (1973). See Graham, 490 U.S. at 397. Friendly's substantive due process test considered (1) the need for the application of force; (2) the relationship between that need and the amount of force that was used; (3) the extent of the injury inflicted; and (4) whether the force was applied in a good faith effort to maintain or restore discipline or maliciously and sadistically for the very purpose of causing harm. See Glick, 481 F.2d at 1033. Instead, the Graham Court adopted the more plaintiff-friendly objectively reasonable test. See Graham, 490 U.S. at 399. Judge Friendly's test was adopted by the Court, however, in determining whether excessive use of force by a guard against a convicted prisoner during a riot violated the Eighth Amendment. See Whitley v. Albers, 475 U.S. 312, 320-21 (1986) (" $[T]$ he question whether the measure taken inflicted unnecessary and wanton pain and suffering ultimately turns on 'whether force was applied in a good faith effort to maintain or restore discipline or maliciously and sadistically for the very purpose of causing harm." ). Thus the substantive due process and Eighth Amendment tests for excessive force appear to be identical. $C f$. Revere v. Massachusetts Gen. Hosp., 463 U.S. 239, 244-45 (1983) (concluding that a suspect's or pre-trial detainees's substantive due process right to receive medical care is at least as great as a convicted prisoner's Eighth Amendment protection against deliberate indifference to his medical needs).

${ }^{239}$ See Graham, 490 U.S. at 395 n.10 ("Our cases have not resolved the question whether the Fourth Amendment continues to provide individuals with protection against the deliberate use of excessive physical force beyond the point at which arrest ends and pretrial detention begins, and we do not attempt to answer that question today."). The Eighth Amendment's protection against cruel and unusual punishment, which does not attach until after conviction and sentence, see Ingraham v. Wright, 430 U.S. 651, $671 \mathrm{n} .40$ (1977), applies to all allegations of excessive force against a convicted prisoner. See Hudson v. McMillian, 112 S. Ct. 995, 999 (1992) (holding that the Eighth Amendment standard applies in \$ 1983 action alleging beating of shackled inmate by guard and supervisor). Thus, those citizens who have been successfully seized and arrested but not convicted remain in a legal limbo between the Fourth and Eighth Amendments' prohibitions against excessive force.

The Court has, however, applied the Fourth Amendment's prohibition against unreasonable searches and seizures to pretrial detainees, while refusing to apply the same protection to convicted prisoners. Compare Block v. Rutherford, 468 U.S. 576, 
whether the Fourth Amendment or substantive due process would protect those, like Mr. Cooper, who have been arrested and booked but not yet arraigned or convicted. ${ }^{240}$

The better position is to apply the Fourth Amendment to those pretrial detainees, whether formally charged or not, who were interrogated prior to being imprisoned or who have been separated from the general prison population for purposes of interrogation. ${ }^{241}$ In such situations, application of the less-exacting subjec-

589-90 (1984) (concluding that pretrial detainees maintain limited Fourth Amendment rights similar to those discussed in Bell v. Wolfish) and Bell v. Wolfish, 441 U.S. 520,557 (1979) (evaluating conditions of pretrial detention under the Fourth Amendment's punishment standard) with Hudson v. Palmer, 468 U.S. 517, 526 (1984) (holding that a convicted prisoner has no reasonable expectation of privacy in his prison cell and thus has no $\S 1983$ action based upon a Fourth Amendment violation).

${ }^{240}$ Compare Bender v. Brumley, 1 F.3d 271, 277 (5th Cir. 1993) (finding that where plaintiff in $\$ 1983$ suit alleged that officers physically beat him during interrogation, Fourth Amendment was inapplicable and test to determine whether police used excessive force against this pretrial detainee, in violation of the Due Process Clause of the Fourteenth Amendment, was Eighth Amendment inquiry as to "whether force was applied in a good-faith effort to maintain or restore discipline, or maliciously and sadistically to cause harm"); United States v. Cobb, 905 F.2d 784, 788 n.7 (4th Cir. 1990) (using Judge Friendly's more rigorous substantive due process test to find that officers were properly convicted under 18 U.S.C. $\$ 242$ of using excessive force against a pretrial detainee, and thus declining to reach difficult question of whether protections of Fourth Amendment extend to pretrial detainee), cert. denied, 498 U.S. 1049 (1991) and Wilkins v. May, 872 F.2d 190, 193-95 (7th Cir. 1989) (holding that where plaintiff in $\S 1983$ and Bivens suit alleged that officers held gun to his head during interrogation occurring after arrest but before plaintiff was charged, conduct may violate due process if it shocks the conscience, but Fourth Amendment reasonable test does not apply), cert. denied, 493 U.S. 1026 (1990) with Austin v. Hamilton, 945 F.2d 1155, 1162 (10th Cir. 1991) (holding that in Bivens action against federal agents for beatings during detention, Fourth Amendment applied post-arrest until arrested suspect's first judicial hearing, at which time substantive due process test applied) and Gonzalez v. Tilmer, 775 F. Supp. 256, 260-61 (N.D. Ill. 1991) (considering $\S 1983$ cause of action against the police for use of force during plaintiff's 48-hour detention before arraignment, and holding that the Fourth Amendment protects such arrestees, while the Fourteenth Amendment's substantive due process analysis is not applicable until after a suspect is formally charged).

As can been seen from the above case descriptions, some courts that do apply the Fourth Amendment's protection against excessive force beyond the arrest stage distinguish between those not yet formally charged (where the Fourth Amendment applies) and those arraigned by a judicial officer and awaiting trial (where substantive due process applies). I argue that the policies supporting application of the Fourth Amendment to interrogation of uncharged suspects apply equally to the interrogation of suspects who are formally charged. See infra note 243 .

${ }^{241}$ One commentator suggested that the use of "gratuitously cruel" interrogation techniques that fail to coerce a confession leave their victim with an excessive force claim, not a self-incrimination claim. See Dripps, supra note 205, at 633. Professor Dripps advocates the elimination of the Self-Incrimination Clause from the Fifth 
tive test cannot be justified by the usual reasons given in Eighth Amendment jurisprudence-the penological interest in security ${ }^{242}$ and the fact that these individuals have already been properly convicted of a criminal offense and thus cannot complain of certain punishments. ${ }^{243}$

Amendment, and the regulation of confessions under the Fourth Amendment, by requiring warrants from magistrates before interrogation of a suspect commences. See id.

${ }^{242}$ See Whitley, 475 U.S. at 324-25 (holding that infliction of gunshot wound to convicted prisoner, in the course of prison security measures taken by guards to quell riot and rescue hostage, does not amount to cruel and unusual punishment even if that degree of force was unreasonable, only the unnecessary and wanton infliction of pain is actionable under $\$ 1983$ ). In light of the overriding responsibility of prison officials to maintain the safety of prisoners, visitors, and guards, and the ever-present potential for violent confrontation requiring hastily made decisions, the Whilley Court rejected the "deliberate indifference" standard used in Estelle v. Gamble, 429 U.S. 97, 104 (1976) for providing medical attention to inmates, and instead adopted the stricter test outlined by Judge Friendly in Glick, 481 F.2d at 1033. See Whilley, 475 U.S. at 319-21. That is, the Court required the prisoner to prove that the state official acted "maliciously and sadistically for the very purpose of causing harm." Id. at 320-21.

Pretrial detainees undergoing interrogation, by contrast, are already removed from the general prison population and thus pose little threat of rioting, smuggling contraband or weapons, or otherwise causing a disturbance. Cf. Bell, 441 U.S. 520, 546 (1979) (holding that maintaining institutional security and preserving internal order are essential goals that may require limitation of retained constitutional rights of both convicted and pretrial detainees).

${ }^{243}$ This less protective standard is appropriate in Eighth Amendment analysis, according to the Court, because the Eighth Amendment, as opposed to the Fourth, applies only after the State has criminally convicted an individual. See Graham, 490 U.S. at 398 (" $[\mathrm{T}]$ he less protective Eighth Amendment standard applies 'only after the State has complied with the constitutional guarantees traditionally associated with criminal prosecutions." ) (citation omitted); Bell, 441 U.S. at 535 n.16 (noting that a sentenced inmate can be punished, "[a]lthough that punishment may not be cruel or unusual under the Eighth Amendment"); see also Turner v. Safley, 482 U.S. 78, 94-99 (1987) (concluding that prisoners' rights are subject to substantial restrictions as a result of conviction, thus infringements upon the substantive due process right to marry and First Amendment right to write letters do not receive strict scrutiny, but rather are appropriate if "reasonably related to a legitimate penological interest"); Palmer, 468 U.S. at 522-30 (holding that the circumscription or loss of many rights associated with imprisonment is necessary to accommodate the institutional needs and objectives of prison facilities, particularly internal security and safety); Rhodes $v$. Chapman, 452 U.S. 337, 345-47 (1981) (finding that, as a function of punishing convicted persons, prison conditions are typically part of the State's legitimate restraint of liberty).

While some restrictions upon the liberty interest of an individual accused of a crime are permissible to ensure that he is available for trial, such a detainee retains her right to be free of punishment. See Bell, 441 U.S. at 534-37 (noting that although detention interferes with the detainee's desire to live as comfortably as possible, confinement does not convert the conditions or restrictions of detention into punishment); Gerstein v. Pugh, 420 U.S. 103, 114 (1975) (recognizing that the government 
Assuming the Court adopts the reasoning above, it could mandate obedience to the dictates of Miranda by holding that any police action resulting in a confession that is subsequently determined to be actually coerced constitutes "excessive force." 244 This has a number of advantages over a substantive due process test. First, the standard for determining whether a violation has occurred, the "objective reasonableness" standard, would eliminate inquiry into an officer's state of mind. Second, this standard would be easier for the plaintiff to prove. Finally, the Court prefers to rely on specific constitutional provisions rather than due process. ${ }^{245}$

To fully enforce Miranda, however, the Court would also have to hold that all intentional violations of Miranda by state or local officials constitute excessive force within the meaning of the Fourth Amendment, regardless of whether those violations result in no confession or a voluntary one. In the latter situation, grafting an intentionality requirement will allow the officer who mistakenly fails to administer the warning properly (the "technical violator") to escape liability, while deterring those who intentionally attempt to circumvent the Court's rules of behavior. This standard would require the plaintiff to establish the officer's state of mind. Proving her intention to violate Miranda, however, would still be less onerous than proving that the officer acted sadistically with the

may permissibly detain a person suspected of committing a crime prior to a formal adjudication of guilt). This makes sense in light of the fact that many interrogations occur after arrest but prior to arraignment. In such a situation, the suspect is closer in circumstance, and presumably in rights, to an ordinary citizen than a convicted offender.

${ }^{244}$ To reach those instances where psychological pressures produce a coerced confession, the Court would need to overrule those cases holding that mere allegations of verbal abuse do not present actionable claims under $\S 1983$. See McFadden v. Lucas, 713 F.2d 143, 146 (5th Cir.) (finding that not every instance of threatened violence or intentionally inflicted injury gives rise to a $\$ 1983$ claim), cert. denied, 464 U.S. 998 (1983). In making its decision, the Court will also have to confront the reluctance of most courts to apply the Fourth Amendment in an interrogation setting. See Cooper I, 924 F.2d 1520, 1530 n.19 (9th Cir. 1991), rev'd en banc, 963 F.2d 1220 (9th Cir.) (holding Fourth Amendment excessive force claim inapplicable "as little physical force was employed against Cooper in his arrest"), cert. denied, 113 S. Ct. 407 (1992); Wilkins, 872 F.2d at 195 (concluding that courts should not "monitor the details of police interrogations" since due process liberty interest "is not freedom from unlawful interrogations but freedom from severe bodily or mental harm"). But see Gonzalez, 775 F. Supp. at 262-63 (finding that while the Fourth Amendment continues to protect arrestees until formally charged, the denial of food to plaintiff during his 48-hour detention did not amount to unreasonable use of force).

${ }^{215}$ See supra notes 227-28 (citing cases in which the Court was reluctant to expand the concept of substantive due process). 
intent to cause harm or to engage in behavior that shocks the conscience, as required under the due process standard.

\section{Reconstitutionalize Miranda}

The simplest solution is to return Miranda to its constitutional roots by establishing that the recitation of the warnings is the constitutionally required method of protecting the privilege against self-incrimination. ${ }^{246}$ Justice Douglas ${ }^{247}$ and, more recently, a number of scholars have championed this position. ${ }^{248}$ It is the present interpretation of Miranda as conclusively presuming that all statements taken during unwarned custodial interrogation are involuntary, that makes its exclusionary rule prophylactic. Because the Court has held that some statements taken in violation of Miranda are actually voluntary, despite this presumption, it is possible that a federal court will overturn a state court criminal conviction based upon the admission of a statement consistent with the Federal Constitution, although inconsistent with Miranda. ${ }^{249}$ The most vigorous response to this criticism is tendered by Professor Schulhofer, who suggests that Miranda, rather than offering a conclusive presumption, actually offers a constitutional interpretation that compulsion is, by definition, present in every custodial interrogation, and thus the Fifth Amendment is actually

${ }^{246}$ This would of necessity include the requirement that the Self-Incrimination Clause apply at the station house as well as in the courtroom.

${ }^{247}$ Dissenting in Michigan v. Tucker, Justice Douglas opined that 'Miranda's purpose was not promulgation of judicially preferred standards for police interrogation, a function we are quite powerless to perform; the decision enunciated 'constitutional standards for protection of the privilege' against self-incrimination." 417 U.S. 433, 465-66 (1974) (quoting Miranda v. Arizona, 384 U.S. 436, 491 (1966)) (Douglas, J., dissenting). Douglas believed that if Miranda warnings were not required by the Constitution, the Court should not have required them, for if Miranda warnings function simply to punish officers rather than as a constitutional right of the defendant, then "the Court's action in adopting [them] sounds more like law-making than construing the Constitution." Id. at 465 (quoting Linkletter v. Walker, 381 U.S. 618, 649 (1965)) (Black, J., dissenting).

${ }^{248}$ See Ogletree, supra note 38, at 1842 (stating that the per se exclusion of custodial statements made in the absence of counsel is preferable even to the current Miranda warnings and would better protect the Fifth Amendment privilege against self-incrimination); Schulhofer, supra note 28, at 461 (arguing that the Miranda warnings are necessary to protect a suspect's constitutional rights and that "Miranda's safeguards deserve to be strengthened, not overruled ${ }^{n}$ ).

${ }^{249}$ This also raises the specter of Article III illegitimacy. See supra notes 58-59 and accompanying text (noting that several commentators have forcefully urged that the Court has no authority to overturn a state court criminal conviction absent a federal constitutional violation). 
violated in every case, unless the warnings are given. ${ }^{250}$

While Schulhofer's argument eliminates the need to justify Miranda as a prophylactic rule, it depends upon the acceptance of a rather strained definition of compulsion. ${ }^{251}$ Moreover, a number of additional problems come to mind. Initially, his theory may require the reversal of all cases that hold that a Miranda violation is not a constitutional one. Consequently, any statement obtained in violation of Miranda would be disallowed for purposes of impeachment, obtaining other leads, and so forth. Aside from potentially impeding the truth-seeking function of a trial, this practice may offer undue advantage to the defendant by requiring the prosecutor to stand idly by while the defendant escapes punishment by committing perjury. ${ }^{252}$ Alternatively, it may be possible to allow statements taken in violation of Miranda to be used for impeachment by employing a balancing test. To be sure, the Court balances government action against individual liberty in certain areas of constitutional law. ${ }^{253}$

An additional hurdle must be overcome before such an approach would permit a $\$ 1983$ action for a Miranda violation. Even if it is established that every unwarned statement is "compelled," such statements must still be introduced in "criminal proceedings. ${ }^{254}$ The reconstitutionalized Miranda doctrine could

${ }^{250}$ See Schulhofer, supra note 28, at 446-47 ("The [Miranda] Court did not hold that a brief period of interrogation can involve compulsion. The Court held that the briefest period of interrogation necessarily will involve compulsion."). In the Fifth Amendment context, compulsion means "pressure imposed for the purpose of discouraging the silence of a criminal suspect." Id. at 445 (emphasis omitted). It is the reason for the pressure rather than its amount that is significant. See id. "Custodial interrogation brings psychological pressure to bear for the specific purpose of overcoming the suspect's unwillingness to talk, and it is therefore inherently compelling .... Id. at 446. Thus, one interpretation of Schulhofer's article is that, in essence, the conclusive presumption of compulsion is not a presumption at all, but a logical and factual certainty.

${ }^{251}$ See Grano, Constitutional Difficulties, supra note 59, at 182-86 (arguing that Schulhofer's interpretation of the word "compelled" is implausible).

${ }^{252}$ See Oregon v. Hass, 420 U.S. 714, 723-24 (1975) (holding that although the accused was questioned in violation of Miranda, his statements could be used to impeach his conflicting testimony at trial).

${ }^{253}$ For example, the First Amendment protection of free speech can be abridged if there is an overriding government justification. See, e.g., Dennis v. United States, 341 U.S. 494, 503 (1951) ("[T]he societal value of speech must, on occasion, be subordinated to other values and considerations.").

${ }^{254}$ See supra notes 85-118 and accompanying text (discussing the fact that the failure of police officers to give Miranda warnings does not deprive a suspect of his constitutional rights unless statements obtained during the interrogation are used against the suspect at trial). 
avoid this requirement by holding that the station house is part of the continuing criminal proceeding for purposes of the Fifth Amendment. ${ }^{255}$ Such a reading would enable a civil rights suit against the interrogating officer regardless of whether she was a witness at trial (defeating the acting under color of law restriction), and regardless of whether her statements were the proximate cause of the judge's ruling (making the judge's admittance of the statement irrelevant). ${ }^{256}$

A better way to justify Miranda $a^{257}$ or any prophylactic rule, however, is by identifying it as constitutional common law. The Miranda decision itself began, perhaps inadvertently, down this path. The warnings promulgated by Miranda cannot be categorized as garden-variety common law, for Congress could then simply create legislation to overrule that requirement without providing a "fully effective" alternative procedure. ${ }^{258}$ Moreover, these warnings cannot be categorized as true constitutional interpretation, for then Congress would be unable to replace them with a procedure

${ }^{255}$ This is possible only upon an expansive reading of the words contained in the Self-Incrimination Clause. See David Dolinko, Is There a Rationale for the Privilege Against Self-Incrimination?, 33 UCLA L. REV. 1063, 1082 (1986) (criticizing the Miranda Court's ruling that a suspect's rights in a pretrial interrogation are grounded in the Fifth Amendment because at its "core" that Amendment protects against compelled self-incrimination only in judicial proceedings). The privilege has been extended, however, to grand jury and juvenile proceedings. See supra note 85 . While there are still situations in which the compulsion to speak is the result of a formal process, "as a practical matter, the compulsion to speak in the isolated setting of the police station may well be greater than in courts or other official investigations, where there are often impartial observers to guard against intimidation or trickery." Miranda v. Arizona, 384 U.S. 436, 461 (1966).

${ }^{256}$ See supra part II.B (explaining why it is virtually impossible to successfully bring a $\$ 1983$ action for a violation of the Self-Incrimination Clause).

${ }^{257}$ Certain commentators argue that even as a presumption or prophylactic rule, the Miranda decision should stand. They make these arguments, however, by referring to social policy rather than offering any source of constitutional authority. For example, Schulhofer noted that the Court permits prophylactic rules in other areas of constitutional law, such as conclusively presuming a First Amendment violation from the possibility that certain kinds of statutes will chill speech. See Schulhofer, supra note 28 at 448-51. In particular, Schulhofer argues that these irrebuttable presumptions "minimize adjudicatory error" and are appropriate tools in a particular context. Id. at 450-51. In the context of the Fifth Amendment, the due process case-by-case approach left courts and police without the proper guidance and thus failed to stem compulsion. See id. at 451-52; see also David Strauss, The Ubiquity of Prophylactic Rules, 55 U. CHI. L. REv. 190, 191-95 (1988) (arguing that prophylactic rules are a central and necessary feature of constitutional law, particularly in the First Amendment area, and that conclusive and rebuttable presumptions differ only in degree, not in kind).

${ }^{258}$ Miranda v. Arizona, 384 U.S. 436, 444 (1966). 
of its own making, absent a constitutional amendment. I believe Chief Justice Warren, whether consciously or not, was promulgating a controversial genre of constitutional law. Previous constitutional interpretation divined the "core" meaning of constitutional provisions, which meaning did not change over time and did not directly depend upon policy or empirical decisions. This alternative class of constitutional interpretation is more fluid. The remainder of this Article reflects my own conception of the Constitution.

Professor Monaghan first coined the phrase "constitutional common law" in 1975, noting that

a surprising amount of what passes as authoritative constitutional "interpretation" is best understood as something of a quite different order-a substructure of substantive, procedural, and remedial rules drawing their inspiration and authority from, but not required by, various constitutional provisions; in short, a constitutional common law subject to amendment, modification, or even reversal by Congress. ${ }^{259}$

I would modify Monaghan's theory and posit that constitutional common law is in fact required by the Federal Constitution in some instances, but this requirement is temporary and/or conditional. Some remedy or procedure is necessary to safeguard a constitutional provision, but the Constitution itself does not specify which remedies or procedures to utilize. Thus it becomes the Court's obligation under the Constitution to create the body of law necessary to guarantee that particular constitutional right against whatever danger it faces. ${ }^{260}$ The necessary or appropriate reme-

${ }^{259}$ Monaghan, supra note 10, at 2-3; see also Martha A. Field, Sources of Law: The Scope of Federal Common Law, 99 HARV. L. REV. 881, 888-90 (1986) (arguing in favor of an expansive approach to federal common law and against differentiating between federal common law and constitutional common law). For opponents of this doctrine, see, for example, Minnick v. Mississippi, 498 U.S. 146, 166 (1990) (Scalia, $\mathrm{J}$., dissenting) (criticizing the majority for instituting prophylactic rules beyond the Court's constitutional authority). See generally Thomas S. Schrock \& Robert C. Welsh, Reconsidering the Constitutional Common Law, 91 HARV. L. REV. 1117 (1978) (arguing that the Court has no authority to create subconstitutional common law, that Monaghan's theory is nothing more than judicial realism that will turn judges into legislators and law into politics, and suggesting instead a return to interpretational constitutionalism).

${ }^{260}$ One instance in which the Court initially appeared to utilize constitutional common law was in creating Bivens damage actions for the violation of constitutional rights. See Bivens v. Six Unknown Named Agents of Fed. Bureau of Narcotics, 403 U.S. 388, 397 (1971). Some commentators believe that this remedy is or should be constitutionally required. See, e.g., Walter F. Dellinger, Of Rights and Remedies: The Constitution as a Sword, 85 HARV. L. REV. 1532, 1557 (1972) (" [C]onstitutional rights 
dies and procedures may change with circumstances and Congress may provide alternative remedies and procedures of comparable effectiveness. This "constitutional common law" has the same status as "true" constitutional interpretation and as federal statutes and would thus be a proper basis for a $\$ 1983$ suit.

In 1994, as in 1966, the Miranda warnings and the exclusion of statements taken in violation of these warnings are constitutionally required as part of the Fifth Amendment's self-incrimination privilege. These warnings may not be required in the future,

have a self-executing force that not only permits but requires the courts to recognize remedies appropriate for their vindication."); Gene R. Nichol, Bivens, Chilicky, and Constitutional Damage Claims, 75 VA. L. REV. 1117, 1121 (1989) (arguing that the Bivens remedy is "an indispensable component of constitutional oversight"). The Court has stressed, however, that the Bivens action springs from federal common law, and thus the Court, in divining congressional purpose, implies this remedy only when Congress so intended. The federal common law in Bivens arose not directly from the Constitution, but rather from the combination of a court's historical ability to provide a remedy for the violation of individual liberties and from the interpretation of 28 U.S.C. § 1331, the federal jurisdiction statute. See Bivens, 403 U.S. at 395-97; id. at 405 (Harlan, J., concurring).

Unfortunately, in fashioning this federal common law, over the years, the Court has altered the test for allowing a Bivens action. The focus of the inquiry has shifted from whether Congress explicitly declared that an individual could not recover money damages for violation of a constitutionally-protected right, to whether Congress offered any remedial mechanism for constitutional violations occurring in a particular government program, even where the plaintiff is not covered by that remedy. Compare, e.g., Carlson v. Green, 446 U.S. 14, 19-23 (1980) (holding that a federal prisoner's right to sue under Eighth Amendment for deliberate indifference to medical needs was not preempted by Federal Tort Claims Act, because the FTCA was not as effective and Congress did not explicitly declare it a substitute) and David v. Passman, 442 U.S. 228, 246-47 (1979) (allowing a suit for money damages under Fifth Amendment for gender discrimination by a Congressman despite Congress's refusal to extend Title VII to congressional staff) with Schweiker v. Chilicky, 487 U.S. 412, $417-18,423$ (1988) (holding that the design of the Social Security Disability Benefits Reform Act of 1984 suggested that Congress had intended it to be the exclusive remedy for the due-process violation of wrongful termination of disability benefits, although the Act did not apply to persons, like plaintiffs, whose benefits had been terminated prior to 1983) and Bush v. Lucas, 462 U.S. 367, 388-90 (1983) (holding that no damage remedy under the Constitution is permitted for federal civil servant's dismissal in retaliation for exercising his First Amendment rights because Congress provided a comprehensive remedial scheme for these employees, although Congress did not declare that its remedy was exclusive).

Had the Court termed a Bivens action part of constitutional common law, it could have looked to the adequacy-rather than to the mere existence-of a congressional remedial scheme in the area affected by the alleged wrongdoing. See Betsy J. Grey, Preemption of Bivens Claims: How Clearly Must Congress Speak?, 70 WASH. U. L.Q. 1087, 1122-29 (1992) (arguing that due to the importance of the constitutional rights at issue, the Court should not deny a Bivens-type damage remedy for a constitutional violation absent a "clear statement" from Congress to the contrary). 
however, due to changed circumstances. For example, if the nature of custodial interrogation were ever to become less compelling (say, if police officers offered suspects tea and crumpets instead of threats and psychological coercion, or if every interrogation were videotaped), ${ }^{261}$ conditions would then have changed such that the present constitutional common-law procedure would be unnecessary. Likewise, if Congress instituted an effective alternative to the Miranda warnings, such as by enacting a statute requiring that defense counsel participate in every custodial interrogation, then again, the warnings would no longer be required. Although the interrogation itself would remain equally intimidating, the Court, in assessing this new procedure, might find the congressional remedy adequate to protect the privilege and thus find the constitutional requirement satisfied. Just as the meaning of certain constitutional provisions may change over time, ${ }^{262}$ the conditions that inform these provisions may change as well.

Naturally, one may ask where the Court derives the authority to create constitutional common law. Although there is certainly no federal general common law to supplant state rules of decision, ${ }^{263}$

261 Two states, Alaska and Minnesota, now have a judicially imposed requirement that law enforcement officers electronically record custodial interrogations. See Stephan v. State, 711 P.2d 1156, 1158 (Alaska 1985) (holding that the unexcused failure to record electronically a custodial interrogation violated suspect's right to due process under Alaska Constitution); Minnesota v. Scales, 518 N.W.2d 587, 592 (Minn. 1994) (requiring the recording of all custodial interrogations, including information about waiver and holding that a substantial violation of this requirement results in suppression of statement).

${ }^{262}$ For example, it was only in the late 1950 s that courts began to use the Due Process Clause to disallow confessions coerced by psychological rather than physical means. See, e.g., Haynes v. Washington, 373 U.S. 503, 504 (1963) (describing a suspect's 16-hour interrogation in which he was repeatedly told that if he "cooperated" he would be allowed to contact his wife and attorney). In 1954, the Supreme Court repudiated a century-old doctrine by holding that the Equal Protection Clause no longer allowed separate but equal education for African-Americans. See Brown v. Board of Educ., 347 U.S. 483, 495 (1954). In 1973, the privacy penumbra of the Bill of Rights began protecting a woman from state interference in her decision to terminate her pregnancy. See Roe v. Wade, 410 U.S. 113, 155 (1973). In 1994, hopefully, the Equal Protection Clause will be interpreted to provide protection against discrimination to gays and lesbians. For a further discussion of changes in the meaning of various constitutional principles, see LAURENCE H. TRIBE, AMERICAN CONSTITUTIONAL LAW $\$ \S 3-4$, at 33 (1978) (suggesting that constitutional law is not determinate, but rather that "the Constitution remains a fundamentally democratic document, open to competing interpretations limited only by the values which inform the Constitution's provisions themselves").

${ }^{263}$ See Erie R.R. v. Tompkins, 304 U.S. 64, 78 (1938) (holding that federal courts sitting in diversity cases must apply state law to substantive questions, rather than 
there is a species of federal common law appropriate in cases of overriding federal interest, such as interstate and international disputes, disputes concerning the rights and obligations of the United States, and admiralty cases. ${ }^{264}$ Moreover, inherent in the process of federal court decision-making is the need to create federal common law to fill the legislative gaps in federal statutes. $^{265}$ Concerns of federalism and separation of powers are somewhat allayed by the fact that the Court is merely divining congressional purpose by looking directly to the words, structure, legislative history, and purpose of the statute, and because of the need for a uniform national rule of law. ${ }^{266}$

A court has a similar duty to assess the constitutionality of state

"declare substantive rules of common law").

${ }^{264}$ See Texas Indus., Inc. v. Radcliff Materials, Inc., 451 U.S. 630, 641 (1981) (" $[F]$ ederal common law exists only in such narrow areas as those concerned with the rights and obligations of the United States, interstate and international disputes . . , and admiralty cases.") (citation omitted); see also Moragne v. States Marine Lines, 398 U.S. 375, 378 (1970) (allowing action for wrongful death to be brought in federal court under admiralty law) (superseded by 33 U.S.C. $\$ \$ 901-50$ (1988)); Banco Nacional v. Sabbatino, 376 U.S. 398, 427 (1964) ("[T]he scope of the act of state doctrine must be determined according to federal law.") (superseded in part by 22 U.S.C. $\$ 2370(\mathrm{e})(2)(1988)$, which created limited exceptions to the act of state doctrine); Clearfield Trust Co. v. United States, 318 U.S. 363, 366-67 (1943) (stating that the Court must fashion federal common law to resolve a dispute between the United States and a bank).

${ }^{265}$ See, e.g., DelCostello v. International Bhd. of Teamsters, 462 U.S. 151, 158-63 (1983) (employing federal common law to determine the statute of limitations for an employee's suit for breach of a collective bargaining agreement); Merrill Lynch, Pierce, Fenner \& Smith, Inc. v. Curran, 456 U.S. 353, 374-95 (1982) (inferring a private cause of action under the Commodity Exchange Act) (superseded by 7 U.S.C. $\S 25$ (1988)).

Unfortunately, in the civil rights arena, the post-Warren Courts have used federal common law almost exclusively to limit the substantive scope of $\S 1983$ and Bivens actions. See, e.g., Schweiker v. Chilicky, 487 U.S. 412, 420-29 (1988) (barring a Bivens action to recover damages for a due process violation that resulted from the wrongful termination of social security disability benefits because congressional passage of the 1984 Reform Act provided an adequate remedial mechanism); Pennzoil Co. v. Texaco, Inc., 481 U.S. 1, 10-18 (1987) (erecting a heightened irreparable harm requirement, based on principles of federalism, for $\S 1983$ injunctions against unconstitutional state actions); United States v. Stanley, 483 U.S. 669, 683-84 (1987) (holding that a Bivens action could not be maintained by a former serviceman against military officers and civilians for injuries resulting from nonconsensual administration of the drug LSD because of the special factor that the experiment arose in the course of an activity incident to military service); City of Los Angeles v. Lyons, 461 U.S. 95, 111-13 (1983) (imposing limits on federal court power to intervene in unconstitutional practices of local governments).

${ }^{266}$ For a general discussion of federal common law, see PAUL M. BATOR ET AL., HART AND WECHSLER'S THE FEDERAL COURTS AND THE FEDERAL SYSTEM 849-959 (3d ed. 1988). 
and federal action in the cases before it. In a civil rights action in which a plaintiff alleges a constitutional violation, or in a criminal prosecution in which the government attempts to deprive an individual of constitutionally-guaranteed liberties, the court must interpret how the Constitution limits the activities of those state and federal officials. To accomplish this, the Court must divine the Framers' purpose (if relying on strict constructionism) or the present meaning of the Constitution (if relying on judicial realism) by looking to the words, structure, and purpose of the Constitution. This is precisely the road that the Court travels when it creates federal common law in a statutory context.

There are numerous advantages to finding that constitutional common law is constitutionally required. First, it answers the Article III legitimacy question. The Court would decide a case "arising under this Constitution" in refusing to incarcerate an individual whose conviction is based upon a Fifth Amendment violation, and could, pursuant to the Supremacy Clause, ${ }^{267}$ overturn state convictions so based. Such a finding would also allow a plaintiff to bring a $\S 1983$ action based upon a violation of the constitutional common-law prophylactic rule.

Likewise, there are many advantages to using constitutional common law rather than constitutional interpretation. Built into these advantages are automatic limits on the dangers of expanding the Court's role in this manner. Initially, the use of constitutional common law would ensure that constitutionally guaranteed rights would have the same contours regardless of the state in which a citizen lived. Without either a constitutional interpretation of the Fifth Amendment or constitutional common law requiring Miranda's exclusionary rule, the rule is illegitimate (as applied to state courts) under Article III, and a citizen should receive no protection from it. If, however, the Constitution does require some deterrence mechanism, but the Court cannot fashion constitutional common law, then the Court is limited to a case-by-case determination of whether the state in which the defendant resides has provided a relief mechanism. Again, the protection would vary among citizens of different states. A related advantage to using constitutional common law is that by springing from the Constitution itself, it

${ }^{267}$ See U.S. CONST. art. VI, cl. 2 ("This Constitution, and the Laws of the United States which shall be made in Pursuance thereof . . . shall be the supreme Law of the Land; and the Judges in every State shall be bound thereby, any Thing in the Constitution or Laws of any State to the Contrary notwithstanding."). 
protects individual rights in a principled manner. This quality preserves judicial integrity by shielding justices from the criticism that they are merely implementing their own versions of the social good and by giving their rulings the force of law they deserve.

There are, of course, federalism concerns with prescribing detailed rules for state actors to follow. The Court has already determined, however, that to dispel the coercion inherent in custodial interrogations, law enforcement officials must be given a concrete rule to follow (the warnings), and suspects must be given a remedy to deter violations of the rule (the exclusionary rule). Constitutional common law, via the Supremacy Clause, trumps any conflicting state laws or practices and is made necessary by the state's own failure to control its public officials. Furthermore, the states will have a voice in determining these prophylactic rules through their representation in Congress. Because the rules founded in constitutional common law are not necessarily the only rules capable of safeguarding a particular constitutional provision, Congress can change these rules by offering adequate alternative remedies. ${ }^{268}$ If the Miranda warnings and attendant exclusionary rule were based on traditional constitutional interpretation, then they could never be changed absent a constitutional amendment or express overruling of Miranda.

Finally, in defining the scope of the constitutional common law necessary to protect the privilege, the Court can continue to admit inadvertently unwarned or defectively warned statements to impeach and gather new leads, as such use will not encourage officers to violate Miranda or conduct inherently compelling interrogations. This same constitutional common law, however, can mandate the exclusion-even for impeachment purposes-of any statement made after an officer has deliberately ignored a suspect's requests for silence or counsel. Such exclusion is necessary to compel officers to deliver the warnings and to counteract the otherwise compelling nature of custodial interrogation by someone

${ }^{268}$ This feature vitiates any separation of powers concerns. See Monaghan, supra note 10, at 29, 34-38 ("Extending individual liberty on a common law basis ... triggers an important shift in the political process. The Court, in effect, opens a dialogue with Congress, but one in which the factor of inertia is now on the side of individual liberty.") (footnote omitted). But see Schrock \& Welsh, supra note 259, at $1152-53$ (arguing that Monaghan's subconstitutional common law may precipitate a clash of will between the Court and a Congress that wishes to curtail individual liberties, and that the definitional problems in distinguishing constitutional from subconstitutional pronouncements may increase the frequency of this clash). 
who clearly does not intend to honor a suspect's rights. Likewise, the Court can allow a $\$ 1983$ action when law enforcement officials intentionally ignore Miranda requests for silence or counsel, again because there is a constitutional violation to be deterred. ${ }^{269}$

\section{CONCLUSION}

Those scholars who believe that the Miranda decision was an unwise one are disturbed primarily by the ostensible broadening of the rights of criminal defendants and by the legislative rather than judicial character of the opinion. Such scholars may or may not be appeased or reassured by my attempt to tie that decision more closely to its constitutional moorings. But even those who applaud the deconstitutionalization of Miranda ought to deplore a system in which courts interpret the law in one manner, yet federal and state law enforcement officials ignore this interpretation and instead substitute their own.

Presently, police officers are allowed to apply "cost-benefit" analysis to constitutional or nonconstitutional adjudication, deciding whether to obey certain judge-made rules, or whether a net benefit inheres in breaking these rules and paying the price. By deconstitutionalizing Miranda and holding that no Fifth Amendment violation can occur outside of a courtroom, important decisions concerning the content of citizens' civil rights have been shifted from the judiciary to law enforcement personnel. Courts, legislators, and the general public should recognize that the United States Supreme Court has chipped away at Miranda to the point that it can no longer be called a constitutional requirement and therefore cannot support a $\S 1983$ action. Thus, the extent to which the dictates of Miranda remain in force depends wholly upon the opinions and beliefs of law enforcement officials, as well as the methods they employ in weighing the competing interests of evidence gathering versus freedom from government intrusion. Regardless of whether the fault lies with law enforcement for stretching the limits of court

269 The Court has stated that deterrence of constitutional violations is one of the goals of $\S 1983$. See Memphis Community Sch. Dist. v. Stachura, 477 U.S. 299, 310 (1986) ("'Congress intended that awards under $\S 1983$ should deter the deprivation of constitutional rights. .. . '") (quoting Carey v. Piphus, 435 U.S. 247, 256 (1978)). The intentionality component would be consistent with recent $\$ 1983$ cases requiring intentional state action and is justified by the purpose of the civil rights statute-to curb abusive government practices. 
mandates in this area, or with the courts for failing to enforce their mandates, the situation is an intolerable one.

The various proposals in this Article solve the obstacles to enforcement. Through the use of constitutional common law, the Miranda decision can continue to supply guidance to police officers conducting custodial interrogations, protect the privilege against self-incrimination, conserve resources by providing evidentiary presumptions for judges, and provide a basis for aggrieved plaintiffs to sue pursuant to the civil rights statute. Without some method for enforcement, we have, in effect, repealed the Self-Incrimination Clause sub silentio. We are then doomed to return to those barbaric means of ascertaining truth that the Court has sought to outlaw. 
